\title{
INTIMATE CURRENCIES
}

\section{Love, Romance, and Sex "without Hang-ups"}

In 2000, when I was staying in a hotel in Istanbul at the edge of Taksim Square one evening I was in the lobby just before 7 p.m. I was surprised to encounter two separate groups of young women who appeared to be from the former Soviet Union; they were joking with one another in Russian and touching up makeup, apparently waiting for their friends to join them. When they departed, I asked the hotel clerk if they got many Russian customers, and he laughed disparagingly, saying, "Those girls, they are just dancers!" As I learned the following day, from one of the dancers in the "Ukrainian" group, the young women gathered nightly just before departing for the nightclub around the corner so they could arrive at the club as a unified entertainment troupe. Far from being "just dancers," these women provide a portal onto how intimate economies are being remade in Eurasia as women differentially capitalize on their sexuality "without hang-ups" (bez kompleksov) and also activate intimate currencies of love and romance.

The entertainment industry, in which young women from the former Soviet Union readily find employment in Turkey, is at the crux of this chapter, along with young women's accounts of their experience working as entertainers in Istanbul in the early 2000s. Here I refer to the women interchangeably as "dancers" (tantsory), the term women used to refer to themselves, and "entertainers," a term widely found in literature examining similar types of work revolving around women employed in nightclubs with male clienteles (Tyner 1996; Cheng 2010). In portraying the lives of the post-Soviet dancers I met between 2000 and 2007, I show how they negotiate their insertion into one sphere of global capitalism, 
where their aspirations for mobility are tightly entwined with a shifting politics of sexuality, as well as constrained by states' border regimes. Even as dancers maintain close transnational ties with home, they strive to realize cosmopolitan selves. In contrast to a literature that frames women working as exotic dancers and in other forms of sexualized labor as uniquely victimized by this form of labor (Erokhina 2000; Hughes 2000; Malarek 2003), I draw on feminist scholars writing about the "intimate services economy" and sex work (Agustín 2006; Bernstein 2007a; Cheng and Kim 2014) to consider how post-Soviet women draw on intimate currencies of love, romance, and sex "without hang-ups" as one means of realizing transnational mobility.

\section{Intimate Currencies and Club Life}

One afternoon in 2002 Kara, an entertainer who was halfway through her sixmonth contract, was interested in practicing her English and invited me for tea. I walked up the several flights of stairs to her room and found Kara painting her nails in preparation for her evening's work; she motioned for me to take a seat on one of the three single beds. She had taped handwritten notes with conversational English and Turkish phrases to the wall next to her bed; she laughed and said these were study aids for her work since the more she could converse with clients, the better chance she had of increasing her nightly pay. As clients' bar tabs grew, her cut increased.

Kara explained that she was on her first contract as an entertainer and had sought out this work in frustration over the low pay available back home in Ukraine. In her first job as a telephone operator, a month's work resulted in no more than $\$ 20$. In the other jobs she had attempted—for instance, in a local market, where she would freeze standing outside in winter selling clothing shuttled by her boss from Turkey-she could earn only $\$ 1 /$ day. ${ }^{1}$ At the end of the sixmonth stint in Turkey, Kara was planning on renewing her contract; she was saving money to help send her eighteen-year-old brother to college and to get her mother a visa to work in Italy.

Like several other entertainers, Kara had tried to arrange a marriage through an Internet matchmaking service before seeking work abroad. She corresponded with three men for several months, and for a brief period she dreamed of marrying a man from "that place where a lot of automobiles are made": Detroit, Michigan. In the end, having her letters translated and constantly updating her file with the marriage service was too expensive to keep up; besides, she explained, "It was a silly dream to think that someone else would solve my problems."

In 2001 Kara turned to possibilities for working abroad and visited every European consulate in Kiev to learn about temporary work visa requirements. 
Everywhere she checked required fluency in English or a local language to issue a visa. Kara also looked into arranging work in Italy through a semiofficial network of friends and acquaintances, but she learned that this would cost a minimum of $\$ 350$, and she did not have the money. Turkey was the last resort, a place where everyone knew you could arrange a visa to work in a club without any significant expense, and without knowing Turkish or any other foreign languages.

When I visited with Kara that afternoon, she brought out her photo album, filled with snapshots taken during her time in Turkey. The post-Soviet entertainers I met often flipped through their photo albums full of images taken during expeditions to the beach, birthday celebrations, and special evenings, like New Year's at the club. Similar to Filipinas working as entertainers in South Korea (Cheng 2010, appendix), many post-Soviet entertainers documented their time abroad through the photo albums; these served as a testament to their adventures and allowed women to demonstrate to friends and family their ability to take part in a more cosmopolitan world of Istanbul. Although this could be tricky, as Kara noted, because not everyone knew she was working as a dancer, and in sharing her photographs, she would have to admit to them that she had not been in Italy cleaning houses. Kara's album contained many images of her and other dancers at the kazino, as she referred to the club where they performed nightly. ${ }^{2}$ Kara flipped through images of a day at the beach, dinner out with her most recent Turkish boyfriend, and a New Year's celebration at the club where she was pictured in a white, sequin-laden costume. Here she paused and noted that her costume was wearing out after months of performances, and besides she had gained nearly ten pounds since she arrived in December, so her costume no longer fit as her mother had designed it. Kara laughed with self-deprecation, "Tantsory! [Dancers!] We're supposed to be dancers, but look at us trying to be glamorous!" She added, "But this work is okay; compared to the dreariness of home, it is like a vacation [otpusk]."

In embracing new ways of expressing and performing sexuality, including through pursuit of glamour and related currencies of intimacy, entertainers like Kara sought financial independence and a claim to being modern, mobile subjects (Chu 2010). Unlike post-Soviet shuttle traders or domestic workers and shop assistants in Istanbul, entertainers-who were generally women migrants in their twenties-were largely unconflicted about embodying a sexual persona, putting this to use in their repertoire of "mobility capital" (Dahinden 2010, 330). Post-Soviet women are situated within a long history of "Russian" women as cultural others in Turkey, but they are also products of a particular cultural formation, a socialist one, with resonances in a contemporary time.

In contrast to a much more familiar narrative of women's experiences of mobility in this part of Eurasia as one of victimization at the hand of traffickers 
(e.g., Malarek 2003), I trace instead how women like Kara often saw their aspirations for mobility as impeded by states. Women, and especially younger women, have become subject to forms of control that intensified as states sought to respond to a concern with trafficking in humans. In the case of Turkey, when the US Department of State rated Turkey as a "3" (2002) and then a "Provisional 2" (2003) in the annual Trafficking in Persons (TIP) report, and as Turkey was assessed for potential accession to the EU in the early 2000s, there were significant implications for migrants. The Turkish government was pressured to intensify policing of its borders and turn attention to any women who could have been trafficked, including by conducting bar raids and detaining suspected sex workers. ${ }^{3}$ Moreover, long before these international pressures to increase the policing of borders and public space, for decades Turkey had regulated those it perceived as posing a public health danger (Şimşek et al. 2004). ${ }^{4}$ In this chapter I examine how entertainers negotiate various mechanisms of control, as they capitalize on intimate currencies to pursue their aspirations in Turkey.

In invoking a focus on "intimacy," I aim to portray something of how daily experience, interpersonal exchanges, and larger social structures are shaped by forces of global capitalism. As Ara Wilson (2012) has argued, drawing on a concept of "intimacy" enables us to address shifts in both "domestic" spheres and "public" spaces that are linked to the forms agency can take. The story of post-Soviet women working in Istanbul nightclubs is, in part, the story of some Turkish men's desires for what they imagine to be cosmopolitan forms of sexuality meeting up with post-Soviet women's desires to engage with cosmopolitan spaces. As I show, women seek out work as entertainers, in part, to pursue dreams of modernity, and Turkish men frequent the clubs where these women work in an effort to feed desires for sexual (or at least sexualized) encounters with "modern," exotic women. Similar to Leiba Faier's (2009) work on Filipinas and their relationships with rural men in Japan, my focus is on an "encounter" that in many ways hinges on aspirations for and understandings of modernity. Post-Soviet women entertainers wield what they call their sexuality "without hang-ups" (bez kompleksov) as a sign of their modernity but also as a sort of intimate currency that facilitates their mobility. Women seek to benefit from men's financial expenditures, and women make strategic use of the forms of power they embody by presenting themselves as sexually "liberated," relatively well educated, and phenotypically "white" in urban centers where these qualities are in demand.

Overall, this chapter examines the prevailing tensions entertainers face around expressions of sexuality and intimacy, and I consider how women think about their work in the entertainment industry as linked to independence, romance, and being worldly, three things they often see as impossible in their home countries. 


\section{Socialism, Sexuality, and Intimacy}

While mobility is central in bringing post-Soviet women into the purview of a Turkish male gaze, as Nicole Constable compellingly argues in her work on correspondence marriage between North American men and Filipinas and Chinese women, such encounters do not simply happen but are forged within concrete historical contexts, or "sites of desire," that are shaped by "personal circumstances, personality, imagination, [and] serendipity," but also by distinct histories $(2003,28)$. Post-Soviet women's imaginaries of Turkey and Turkish men are shaped, on the one hand, by popular narratives, such as those featured prominently in telenovelas such as The Magnificent Century, and by contemporary debates around gender, sexuality, and secularism in Turkey. On the other hand, they are also shaped by Soviet discourses around modernity involving sexuality, gender, and intimate encounters.

As labor migrants, post-Soviet women encounter a Turkish public sphere tempered by Turkish models of modernity as well as reactions to secular Turks' efforts to transform society since the early twentieth century. When the women I met commented on the headscarves Istanbullu women sometimes wore or conversions to Islam among their post-Soviet acquaintances, they rarely registered the ways their observations were grounded in a particular historical moment in Turkey where Islamist concerns have increasingly shaped public culture. Instead, they often framed themselves in contrast to Islamist women, implicitly categorizing themselves as "modern" or "civilized" people, different from the dominant population of Turks. Less often women had a more nuanced understanding of the politics involved. For instance, Polina, a woman from Ukraine who worked as a shop assistant, made reference to the legacy of socialism as shaping the performance of gender and related ideals; when I asked her about veiling and how her Turkish boyfriend viewed this, she said: "He would not agree with this; he certainly would not want me to be veiled. He is not like the rest, he is Alevi and a former socialist." In this way, Polina signaled her understanding of the diversity of Turkish communities, including how Kurdish, and specifically Alevi Kurdish, community ideals might differ from dominant ones and the ways that veiling fits within broader political debates. ${ }^{5}$ Whether or not women explicitly discussed the history of socialism and its positioning around gender and sexuality, a common legacy informs the collective identity of postsocialist women migrants.

\section{Sexuality and Intimacy: From the Revolution to Domostroika}

The first years after the Russian Revolution promised a radical departure from the gender regimes that prevailed in Europe in the early twentieth century-a departure that envisioned a society where women would be freed from the demands 
of domestic space, so they could become citizens on par with men. Social theorists and political strategists debated how women's insertion into wage labor and the "withering" of the family would enable women to contribute to a socialist, and ultimately communist, society of equals. This vision of a radically different gender order-sometimes including an ideal of "free love," where sexuality would not be constrained by the institution of marriage-was widely discussed by key social theorists of the time, such as Alexandra Kollontai (2008). ${ }^{6}$ With the revolution in 1917 the Bolsheviks took the first steps to bringing about their radical social vision of gender equality; they established civil marriage and made it possible for either spouse to initiate divorce, and soon afterward they legalized abortion and did away with the idea of "illegitimate" children. The enactment of the 1918 Code on Marriage, the Family, and Guardianship forged the possibility for fundamental change by sweeping away "centuries of patriarchal and ecclesiastical power" and bringing about a new era focused on individual rights and gender equality (Goldman 1993, 49). Organizations such as the Zhenotdel (Women's Department of the Bolshevik Party), which Kollontai cofounded and headed for two years (1920-1921), aimed to educate women in the new laws governing marriage, divorce, and work and to create the conditions where men and women would contribute to and rely on society, instead of the family, including for raising children (Goldman 1993, 2-10; Kirschenbaum 2001).

In the wake of the utopian gender ideals of the 1920s, a much more conservative set of ideals became enshrined in law by the 1930s. As the number of street children and levels of social chaos grew in the aftermath of economic restructuring in the 1920s, the family became a key part of the state's efforts to control its citizenry. In one scholar's words, the state focused on a "repressive strengthening of the family unit" (Goldman 1993, 327) as intrinsic to a new era of social reform. The pendulum swung back toward conservative understandings of marriage, the family, and sexuality and the "withering away" of the family doctrine of an earlier era was negated; as a culmination of the gradual reorientation of dominant policies throughout the 1920s, in 1930 the Zhenotdel was disbanded. As pronatalism and profamily discourses permeated society, in 1936 abortion was once again made illegal, and the idea of "illegitimate" children was again enshrined in law. The Soviet state offered women a "bargain," whereby men would be compelled to support families (including in the form of alimony), but women would need to both take part in the labor force and continue to produce future workers, without an option of abortion and with significantly less provision for state support than early visionaries had imagined (Goldman 1993, 336). As Wendy Goldman evocatively writes, "Stalinist policy toward the family was a grotesque hybrid: rooted in the original socialist vision, starved in the depleted soil of poverty, and ultimately deformed by the state's increasing reliance on repression" 
(1993, 342). Marxist revolutionary ideals maintained a focus on drawing women into the workforce, but this was now seen as crucial for the rapid industrialization of the Soviet Union and no longer linked to ideals of women's "liberation" or the radical vision of "free love."

Depending on the source, very different portraits of Soviet sexuality emerge. According to Anna Rotkirch, the "repressive" period in regard to family and sexuality extended from the 1930s to the 1960s, followed by a period of what she calls "domestication" (1960s through the late 1980s) (2004a, 96). Drawing on autobiographies of people defined by key turning points in sexual culture in Russia, Rotkirch writes of three "sexual generations": those born prior to the Second World War, those born after the war and up to the early 1970s, and those born after the early 1970s. Rotkirch defines the pre-Second World War generation as being defined by "sexual silence" (2004a, 96) and "repression," when there was no accepted space for public discourse on sexuality, abortion was illegal (1936-1955), divorce became difficult, and children born out of wedlock were again stigmatized. Although marriage was not widely seen as a prerequisite to sexual liaisons, sexuality was something to be contained within the private space of a heterosexual, committed relationship.

Rotkirch describes the next sexual generation as the generation of "learned ignorance," and she describes people of this generation as being relatively uninformed about sexuality (2004a, 103). As she explains, the term "sex" (seks) entered popular and more official language, but there was still limited information about sex circulating in Soviet society, and most of it was prescriptive in nature: for instance, focused on proper "sex roles" for boys and girls, or warning teenagers of the supposedly unhealthy effects of masturbation. Rotkirch emphasizes the lack of "sexual revolution" in this period, but others describe this generation as treating sex as a site of resistance to, or at least avoidance of, Soviet power. For instance, Dmitry Shlapentokh writes, "[In the 1970s] sexuality was still one of the few activities in which one could engage without direct supervision of the state and this could explain why Soviet citizens of Brezhnev's era engaged in uninhibited sexual practices" (2003, 120). Vladimir Shlapentokh writes how under Stalin, love was a "refuge," but how especially post-Stalin people could "let themselves go emotionally" with love and sex $(1989,177)$. The very different analytical approaches of these scholars, with one focused on lack of information about sex and the others pointing to "uninhibited sexuality" defining a 1970s generation, suggests that even within generations there were divergent experiences of sexuality, including those based on gender, geography, social hierarchy, and probably moral community (e.g., Muslim, Christian, or secular).

By the late 1980s in the Soviet Union public culture around intimate practices was rapidly changing and people much less frequently associated sex with 
marriage or long-term relationships. The popular press and media provided strong evidence of this shift as it began to openly criticize the poor availability of birth control and the presence of street prostitution (Gessen 1995). An "unbridled" sexual economy following the end of the Soviet Union is pegged by some as being a reaction to the pervasive ethic in grandparents' and parents' generations, where there was a clear separation between, on the one hand, state-enforced "family values," and on the other, the realm of the erotic (Kon 1993, 24; Shlapentokh 1989, 177). In this new milieu a language of sexuality became increasingly commonplace, with a plethora of sources ranging from families as sources of information to self-help books to psychotherapy to media portrayals to a federal sex education program instituted countrywide in high schools by the late 1990s (Gessen 1995; Rotkirch 2004a, 108). The overall result was a widespread ease in discussing sexuality, as well as a sense of sexual knowledge, and the ability for youth, albeit more often in urban settings, to articulate reflections on sexuality.

\section{"Sexuality without Hang-ups"}

Indeed, many young women migrants I met in Istanbul who came of age in the late 1990s and in the early 2000s expressed a sense of sexuality as something to be embraced, as an integral aspect of what made them modern young people. Young women frequently spoke of their lives in a positive light as embodying an ideal of "unrepressed" sexuality or sexuality without "hang-ups." One telling exchange between roommates-Zina, who was no longer cleaning the hotel but working as a domestic in three different houses, and Raia, the Moldovan migrant whose mother encouraged her to accept her boyfriend's advances-reflects this sexual ethic inflected by generation:

Zina: Do you really want to wear those short shorts out on the street [on the way to work as a shop assistant in Istanbul]? I bet you would not even wear them at home to go shopping!

RAIA: I'll wear a long jacket when I go out for work, but actually, at home

[in Gagauzia] I have no problem wearing these shorts [amused laugh]. Zina: Even to pick up your son at day care?

RAIA: I don't really think anything of it; I don't have any hang-ups.

Unlike the older women in their forties and fifties who were working as shuttle traders, shop assistants, or domestics, the younger women, sometimes working as entertainers but also in the same spheres as older women, were explicit about their ease with sexuality. Sometimes young women also emphasized how their sense of sexuality set them apart from both older post-Soviet women and Turkish women. This widespread view among younger women migrants of ideal sexuality 
as being "without hang-ups" was reinforced by common Turkish stereotypes of Russian-speaking women in general. When women travel to Istanbul for work, usually living without family, husbands, or children for months on end, they can appear untethered from kinship networks and the demands of households and family and therefore be seen as sexually available. In her research among Gagauz domestics, Leyla Keough also notes how women from the former Soviet Union and Eastern Europe "transgress traditional Turkish codes of class and gender" and that they are perceived as "ambitious and driven women" and "morally loose or overly sexual" $(2015,106)$. Keough indicates that this perception is heightened by the association of Orthodox Christians with more overt sexuality than is assumed for other women in Turkey. Strikingly, popular Turkish sentiment and young postSoviet women's sentiments converged on this idea that post-Soviet women embody sexual selves, something they both associate with a form of modernity. While Keough briefly analyzes sexualized selves as a double-edged sword, with some Turks finding it alluring and others repelled by it, younger post-Soviet women migrants I met also sought to capitalize on what they considered a sort of intimate currency.

Younger post-Soviet women especially perceived their ability to display what Anthony Giddens has called a "plastic sexuality," a critical element of their allure for Turkish men. Indeed, in public discourses in urban Turkey, post-Soviet women as a group are imagined as having the ultimate plastic sexuality, something that is enticing for some and imminently threatening to others. However, Giddens's definition of "plastic sexuality" as "decentered sexuality, freed from the needs of reproduction" (1992,2) only describes sexuality as a fixed sociological phenomenon. The critical component of how women understand the power of their sexuality and the intimate practices in which they engage requires attention to the ways they foster intimacy over time but also in particular interactions.

\section{Intimate Currencies in the Clubs}

As early as the 1920s Turks and tourists seeking a night on the town have flocked to the central district of Taksim, where there is a concentration of "exotic," relatively upscale nightclubs. This region of the city is viewed as quintessentially modern Istanbul with shopping, high end hotels, chic cafes, and popular restaurants extending from the edge of Gezi Park and Taksim Square along the pedestrian zone of Istaklal Caddesi for nearly a mile to Tünel, where a historical funicular trundles down the steep incline to the mouth of the Golden Horn, just before it spills into the Bosphorus. The post-Soviet migrants I came to know did not generally spend time at the Tünel end of Istaklal Caddesi, but they often spent leisure time in and around Gezi Park, the site of the massive protests in 2013, which were set off by the city's plans to develop the park into a shopping mall. ${ }^{7}$ 


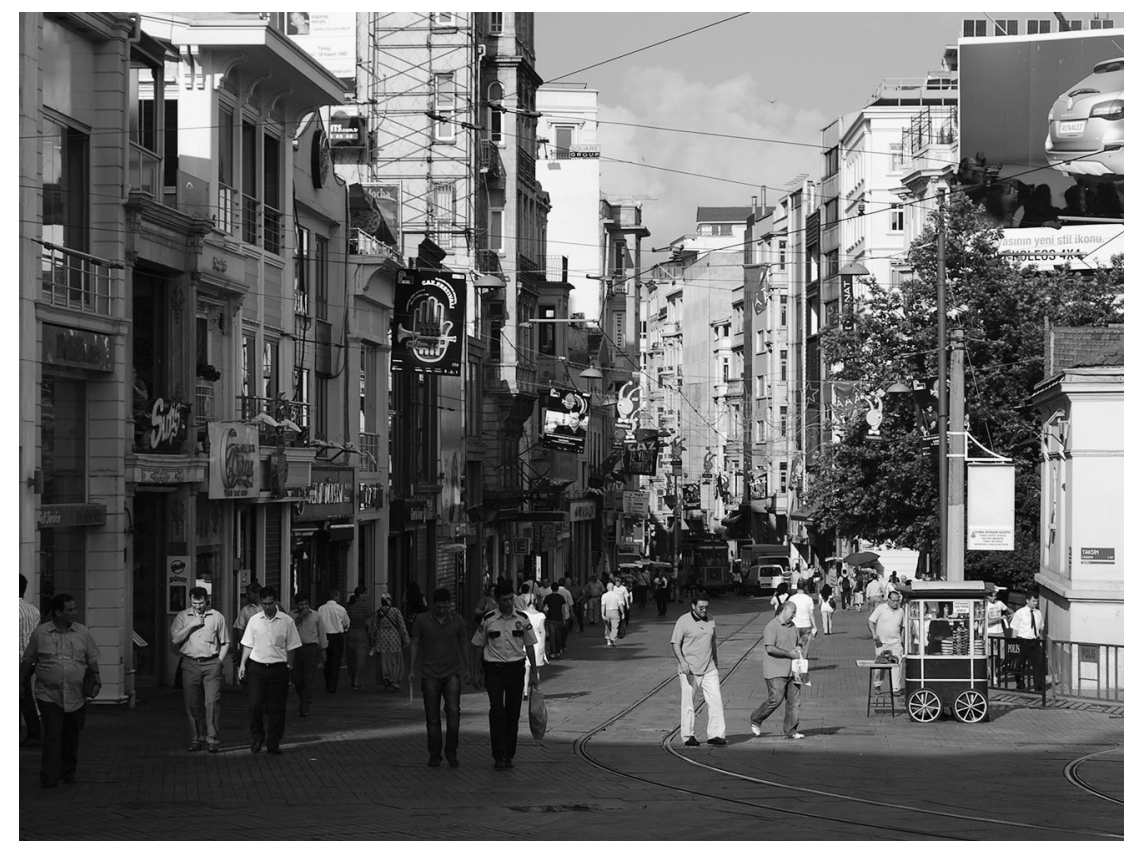

FIGURE 18. On Istaklal Caddesi, near Taksim Square. Photograph by Jared Bloch, 2009.

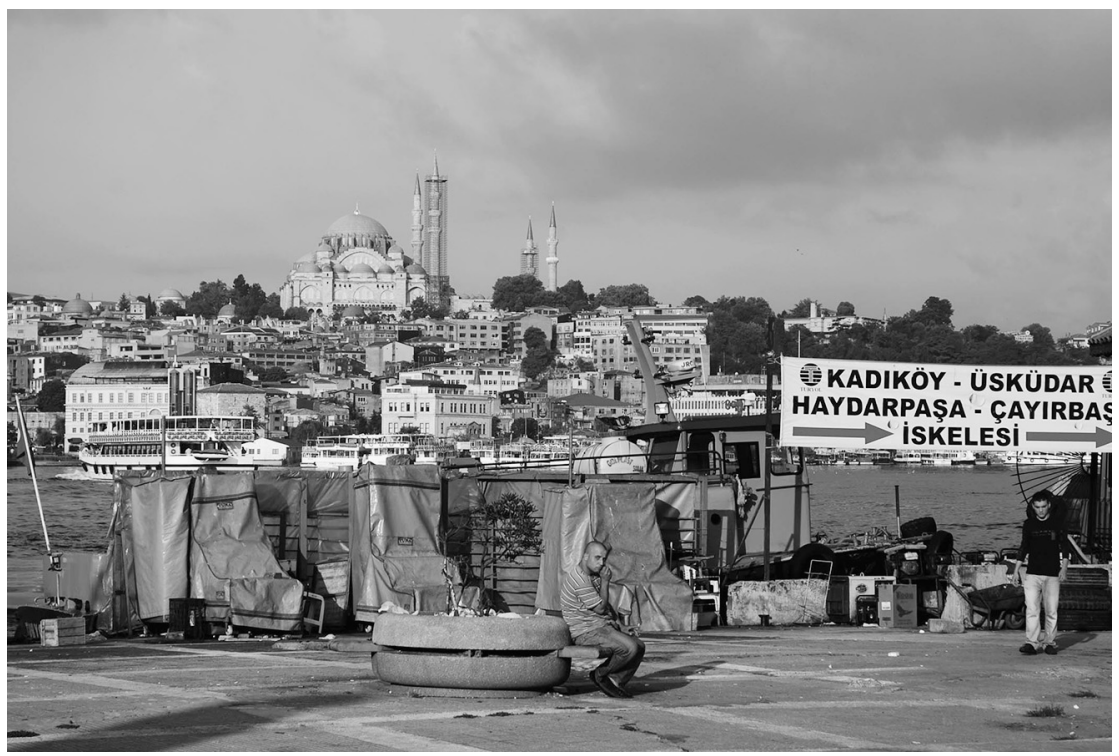

FIGURE 19. On the Golden Horn, looking toward Süleymaniye Mosque. Photograph by Jared Bloch, 2009. 
This relatively rare green space in the densely populated Taksim district is also where I frequently brought my daughter to play in the spring of 2007, when we lived in the neighborhood, and where I sometimes arranged to meet entertainers for interviews at the tea garden, just minutes away from the nightclubs where they worked.

The nightclubs in this region generally cater to high-end guests, including foreign tourists, and they are known for featuring alluring dance numbers (Potuoğlu-Cook 2008). In the mid-1990s several became known for hiring postSoviet women, who often performed in troupes of four to eight people, sometimes including men and women; women told me in 2007 that there were eleven similar night clubs along Istaklal that were hiring post-Soviet entertainers at the time. The owner of the hotel where the entertainers I came to know stayed told me that prior to the post-Soviet dancers, Polish women were hired, and before that, young British women. The entertainers frequently gossiped about the hotel owner's wife, a Polish woman who reportedly first arrived in Istanbul to work as an entertainer and then married one of her customers, the wealthy Turkish man who in 2011 continued to take part in the day-to-day business of the hotel. Similar to the "fairy tale" endings others have written about (Constable 2003; Cheng 2010), on almost a daily basis the dancers were faced with a living testament to the fact that one could work one's way up from a dancer to become an established, and perhaps even wealthy, businesswoman.

With entertainers living in the same hotel as I did, I was able to engage in ongoing discussions with them. Our interactions were sometimes casual-often while the women were preparing for work, applying makeup, fitting bras, or ironing costumes-but I also conducted twelve more formal interviews, as well as maintaining contact with three women, including Kara, for more than a decade. Over research visits spanning several years, I had multiple informal interactions with different groups of entertainers while we relaxed in the hotel lobby watching television, or while they practiced their dance routines, or while they tried out conversational English with me. In addition, by joining in on a number of outings, including on a weekend beach trip and shopping along Istaklal, and attending shows at two of the clubs where women danced, I learned something of their working lives and aspirations.

In many clubs, like the one where the women I met were employed, entertainers both danced and cajoled men to spend as much money as possible. Although some women purportedly engaged in selling sex, in the club context this was not their primary means of making a living. Instead, their pay consisted of a set minimum for each night, with additional pay earned for each "consummation" (konsumatsiia), a term entertainers widely used to refer to securing a customer to join them at a table. Furthermore, a "good" customer bought as many as ten (extremely overpriced) drinks, and women received a commission for each 
drink purchased. In 2007 one club manager explained that entertainers where he worked received $\$ 50$ per night, as well as about $\$ 1.50$ (2 lira) for each drink a customer bought; although this manager thought most dancers made at least an extra $\$ 100$ in tips each night, none of the women I came to know had such earnings. ${ }^{8}$ Entertainers recounted that their success on a given night depended on the effort they made with customers, but also on whether the show was adequately professional in its execution to appeal to customers and whether their managers directed potential customers to their tables.

The dancers I met in Istanbul did not speak of being coerced or deceived into taking on their work, although they did feel that they were paying unfair fees to the agencies that had arranged their visas and working contracts. Due to their contacts with previous migrants, women were mostly aware of the conditions they were to encounter on arriving in Istanbul, and many were on repeat contracts as entertainers or previously had worked abroad elsewhere. Ten of the fifteen entertainers I met in 2002 and 2005 were on their second and third sixmonth contracts as dancers in Turkey; at least two of the women had worked in Poland and the Czech Republic as seamstresses, and one woman had also worked as an entertainer in Greece and Lebanon, where she hoped to return soon because she could renew her tourist visa for up to four months at a time. None of the women had worked as shuttle traders, since they lacked the capital to initiate such a business, although some of them, like Kara, had worked as sales staff, selling wares at open-air markets for an employer. The entertainers generally spoke with disdain about working as vendors back home or domestics in Istanbul; such labor was viewed as far less glamorous and less lucrative than entertainment. Women aspired to upward mobility, which most of them equated with saving enough money to run their own garment import businesses and opening boutiques in their home communities.

For most women, this dream was a distant one. Their work involved long and odd hours-beginning around 7:00 p.m. and sometimes extending until 5:00 a.m.; in 2002 for their labor they typically earned around \$450/month. However, after expenses, they could save barely $\$ 200 /$ month. Still, this was significantly more than the $\$ 20-\$ 50 /$ month women could hope for back home working the unskilled jobs available at the time. After paying the monthly fees for accommodation, and the fee to their "manager" (menedzher) in home countries for arranging the contracts and travel expenses-about $\$ 400$, paid over three months - they could count on a steady monthly income. ${ }^{9}$ They had ongoing daily expenses - including for their costumes and makeup, not to mention food-however, based on their paychecks and tips from fans, several women I knew in 2005 claimed to have sent home $\$ 1,000$ in remittances by the end of their six-month contracts. Those with additional sponsors or wealthy Turkish boyfriends were rumored to be sending $\$ 5,000$ home in the same period. 


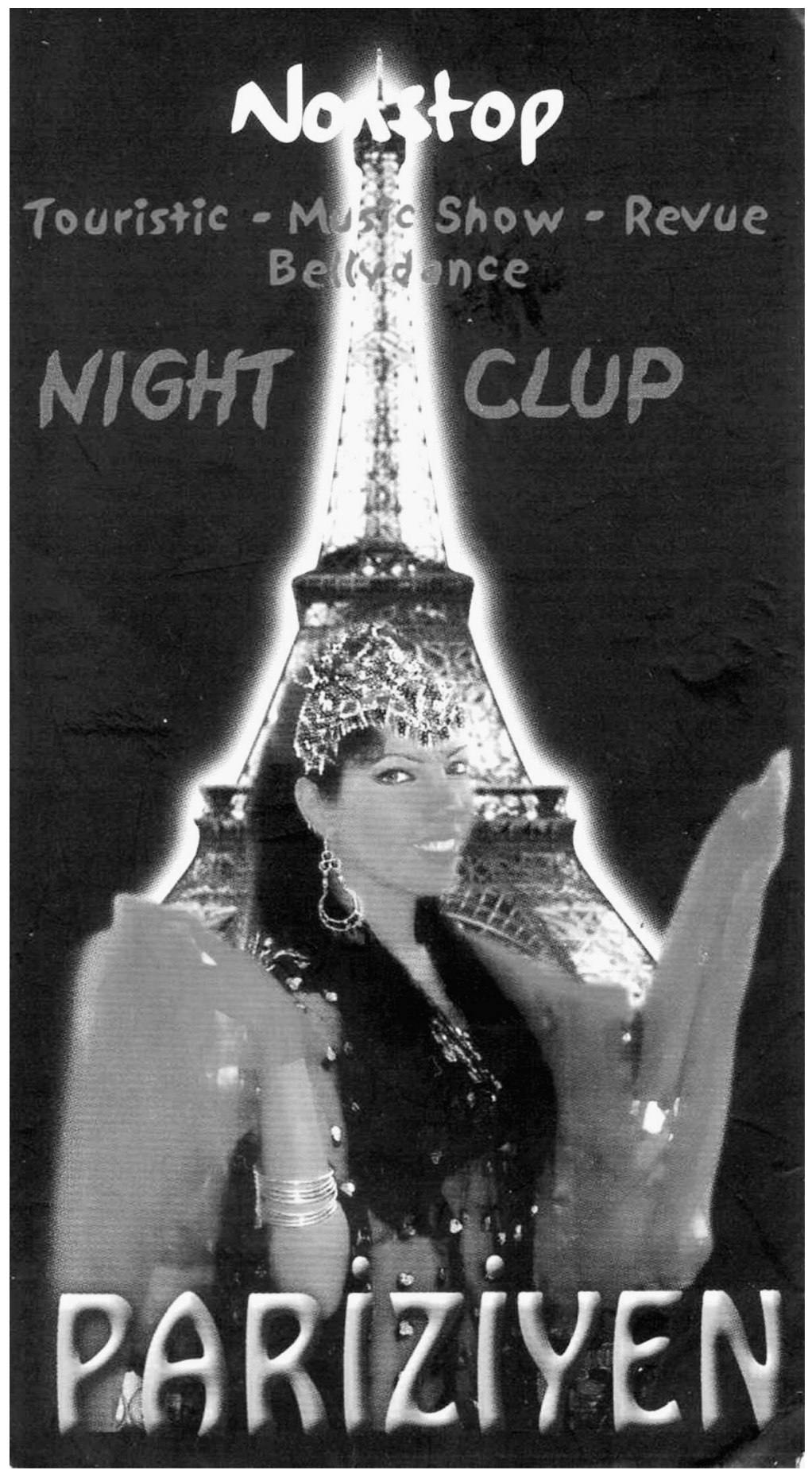

FIGURE 20. Promotional flyer for a Taksim nightclub. 
By 2007 average monthly pay had increased to nearly $\$ 700 /$ month and, while many aspects of the work had not changed, it is significant that dancers began to have more bargaining power. ${ }^{10}$

At least since the 1990s clubs have played a significant role as hosts to the flow of temporary migrant women from the FSU working in the entertainment sector in Turkey. An intermediary, who the entertainers called a "manager," was typically based in women's home countries of Ukraine, Belarus, or Russia and worked for a company that recruited women, made travel and visa arrangements, and, prior to women's departure, often ran basic training around routines women could potentially do together as a performance troupe (Bloch 2009). In 2002 a few women showed me their six-month work visas where type of employment was indicated as "ballerina"; they scoffed at the designation. Some of the entertainers did have training in ballet and other forms of dance, but they viewed themselves more as performers than ballerinas, something they tended to associate with high culture of the Soviet era. ${ }^{11}$ Until 2005 the Turkish clubs arranged with the Turkish Ministry of Labor, and possibly the Ministry of Tourism, to issue six-month visas, and the clubs were also responsible for women obtaining the mandatory monthly medical exams, which included screening for sexually transmitted infections (STIs) and AIDS. ${ }^{12}$ Several women I spoke with were especially outraged by these practices of policing their bodies, since they saw this as equating their work with that of "prostitutes" (prostitutki).

After 2005, when the six-month contracts were no longer available for dancers, clubs increasingly employed women on tourist visas who arrived without any intermediary making prior arrangements and without any performance troupe or "collective" (kollektiv). Women tried to establish performance troupes onsite, but this was difficult, especially as women had different levels of training in dance, and different tourist visa periods, for example, some for one month, some for two months. ${ }^{13}$ As one entertainer explained, clubs also tried to avoid employing the same women for consecutive contracts; the club management said their clientele would get bored if women stayed too long at a club. However, entertainers suspected the constant shift of dancers was an arrangement between the clubs and the police, in part meant to prevent dancers from organizing and demanding better work conditions and pay. In interviews club managers affirmed that they had some arrangements with police; when police were paid off adequately and clubs operated according to parameters set out by them, raids were less frequent. Also, if there were raids, instead of sending post-Soviet women off to the Istanbul detention center for foreigners ("yabancı şube"), police were more likely to demand a modest "fine" and release the women. With bribes, fines, and a frequent rotation of dancers, the police were willing to view dancers as simply "tourists" on overstayed visas who just happened to be in a club. Without the payments, 
entertainers risked being detained or even deported. This is what dancers feared in the spring of 2007, when several clubs in the Taksim district of Istanbul were unwilling to pay what they saw as unreasonable sums to the local police precinct; raids were temporarily stepped up and clubs suffered almost immediately. When for several weeks women who had tourist visas refused to go to work, the club owners eventually paid off the police, and dancers returned to the clubs. Both according to dancers I met and to club owners, police raids were clearly linked to whether or not club owners had fallen behind in paying off the police.

Increasingly, by 2007 entertainers most often located work via their own friendship and kinship networks. In the same year the Turkish Ministry of Labor also began issuing a limited number of entertainer visas for women to work for one year. Most clubs found the process of applying for these work papers onerous, and they continued to risk employing women on tourist visas. In 2007 a club manager told me that about half of the dancers in his Taksim club were on a oneyear work permit, while the others were on tourist visas. ${ }^{14}$ Dancers would stay for the duration of their two-month visas before briefly returning home; they then returned repeatedly for two-month stints at different clubs.

By 2010 dancers also located work via the websites that particularly hotels in southern Turkey began to rely on for recruitment to fill positions during the busy summer season when British, German, and Russian guests arrive in large numbers. ${ }^{15}$ In 2013 some hotels or Turkish companies recruiting for hotels explicitly sought Russian speakers, noting that their clients were predominantly Russian. ${ }^{16}$ The Titanic Deluxe Bilek Hotel posted an advertisement noting that speaking Russian and English was "a must" for the position, with knowledge of Turkish a "plus." The duties for the position included providing parties and concerts for Russian guests (Learn4Good 2013b). Some 2013 advertisements also explicitly sought women who were "attractive" to fill positions as entertainers in nightclubs. ${ }^{17}$ The malleability of the concept of "attractive" is evident, with at least one 2016 advertisement on the same website calling for only "British" and "Scandinavian" men and women to apply for positions as "host/hostess/entertainer," but with a stipulation "no work permit provided, however, very safe working environment is assured" (Learn4Good 2016)..$^{18}$ These shifts and pledges of "safe" work conditions may be linked to Turkish government efforts to safeguard mobile, transnational labor, and thereby signal goodwill in addressing concerns raised by anti-trafficking campaigns on the part of INGOs like the International Organization of Migration.

While the entertainers I met rarely mentioned NGOs' anti-trafficking efforts, and they had not taken note of the IOM anti-trafficking pocket brochures being handed out at the airport, they frequently reflected on how their countries of origin sought to control their movement through borders. This was particularly 
pronounced for those coming from Belarus, as reflected in my conversation with two dancers packing to depart when their two-month tourist visa had come to an end in 2007. Aksana and her friend spoke about their means and routes of travel from Belarus, and how with President Lukashenko's then recent legislation, formal government permission was required to leave the country on anything but a tourist visa. ${ }^{19}$ Even on tourist visas, the easiest way to travel was via Moscow. When Aksana and her friend traveled to Turkey in 2005, they went via Moscow and returned retracing their route, flying from Istanbul to Moscow, traveling by overnight train from Moscow to Vitebsk, Belarus, and finally by bus for several hours to their hometown. Aksana explained that the Russian authorities were much less rigorous than the Belarus ones in policing entries into and exits from the country. Even so, Aksana explained, women generally knew that they must travel na bak, or "with bucks," carrying at least $\$ 300$. Border guards frequently hassled women traveling without a male partner or family member, often demanding evidence, such as a significant sum of money, as proof of women's claims that they were traveling for vacation (not illegal employment). Aksana recalled that during their last trip her friend had been turned back at the border because she did not have the unofficially required $\$ 300$ to show the Russian customs and immigration officials.

These state interventions into intimate spheres of personal finances and autonomy hinder women's mobility and mirror other emerging deportation regimes globally (De Genova and Peutz 2010). Border regimes and policing that target women's mobility are often shaped by states' efforts to demonstrate willingness to combat the trafficking in women. Especially for states marked by a poor rating in the annual US State Department TIP report, as in the case of Belarus (2016), without demonstrable efforts to address concerns about trafficking, they risk losing most favored nation trading status with the United States or at least castigation in the international community. Women's mobility is hindered by the focus on trafficking, but equally important, such a focus has also detracted from finding durable solutions for addressing the working conditions under which undocumented migrants labor. Unlike the situation for some other migrant worker populations, such as Filipinas in Hong Kong (Constable 2007), as of 2011 post-Soviet migrant workers in Istanbul did not have their own dedicated advocacy groups to represent their interests. Instead, international discourses on trafficking continued to emphasize the dangers of women's mobility, framing women as victims of potential traffickers, while disregarding the diverse realities of women's undocumented labor. ${ }^{20}$ In contrast, as the narratives of post-Soviet women in the next section suggest, women's aspirations, desires for glamour, and strategies around making a living as entertainers show them to be far more than 
victims. Moreover, their accounts reflect how mobility and the transformations of intimate economies in Eurasia are interwoven.

\section{Desiring Glamour and Mobilizing Romance: Women's Accounts}

One day when we were looking at Kara's photo album, Zoia, one of Kara's roommates, commented on the shifting reception of Russian-speaking entertainers in Turkey. Zoia, a young woman from southern Ukraine, explained that it was a decent living now, but nothing like ten years ago, as she had heard from older entertainers. At nineteen Zoia was on her second contract, having worked in 2001 in Izmir, a city to the southwest of Istanbul. Zoia lamented that ten years ago the "Russian" women were considered really exotic: "The Turkish men were astonished [her emphasis] by Russian women and they were giving gifts of diamonds and gold. Now they give nothing much." It was not uncommon for such a discourse of glamorous possibilities to be invoked to explain what drew women to seek out work as entertainers in Turkey.

I also heard from Nadia, a young woman from central Moldova, about how the glamour of exotic dancing had changed over time; as the novelty of postSoviet women dancing in clubs wore off, dancing also became less lucrative. As we sat in a tea garden in Gezi Park, Nadia explained how she arrived in Istanbul in 1998 when she was twenty-three. She was immediately drawn to exotic dance both for its glamour and because she could make "good money." Nadia described how at that time work as an exotic dancer was especially well paid, and she found it easy to travel back and forth to Moldova to renew her visa. By the early 2000s, however, these jobs no longer appealed to her since after expenses Nadia could barely take home $\$ 25$ for one night of performing in a club. She turned to other options to pursue her economic aspirations.

When we left the park and walked to her nearby apartment, Nadia told me she was unlikely to return to Moldova any time soon; by staying in Turkey and working as an apartment rental agent, she could finance the construction of a house for her mother and brother back home and support herself. As she pointed to certificates displayed on the wall attesting to her completion of a series of Turkish courses, Nadia relayed that she considered herself "lucky" to have a legal status in Turkey and to be able to pursue various business interests. In 2001, in partnership with her Turkish boyfriend, she opened a property management company and, like thousands of other post-Soviet women, arranged her citizenship through a fictive marriage. Nadia described herself as a shrewd businesswoman who had never risked being "derailed" by romance (see Holland and Eisenhart 1990). 
However, as entertainers often recounted, negotiating the tensions between "love" or romance and money was not always easy. Not all the women I met were as successful as Nadia, but to varying degrees they also sought to mobilize intimate currency in Istanbul as a part of their trajectory for mobility.

\section{The Luxury of Love: Muzhateers, Boyfriends, Friends}

Entertainers frequently saw their time as Kara did, as "a vacation" from dreary hometowns, but like Nadia, they were also focused on economic goals, and fostering intimacy was key to attaining them. Many women sought to maintain a clean division between true intimacy and love versus economic rationality and money. True love became a dangerous luxury when it threatened to derail their primary aim of improving their material circumstances, but it could be a windfall if one could "play" the situation and foster intimacy with those who were adequately prepared to provide financial support. Similar to the Filipina entertainers in South Korea who Sealing Cheng (2007) writes about, the post-Soviet entertainers I met tended to view "true love" as problematic and, at best, fleeting. It was not simple to be immersed in a currency of intimacy and yet retain rigid boundaries between what was genuine and what was strategically enacted emotion; these seemed to blur together often. Women's narratives were saturated with reflections on relationships, and they frequently discussed the tensions between "falling in love," romance, and their material goals.

At the bare minimum women sought to maintain at least one steady relationship with a man who would occasionally take them to dinner and supply them with a cell phone. These relationships were not always viewed as simple commercial exchanges, however, and were sometimes intertwined with emotional ties. Depending on the intensity of these ties and on the level of financial support being provided, the entertainers distinguished between sponsor (muzhateer), boyfriend (blizkii drug), and simply friend (drug) ${ }^{21}$ Women usually only had one sponsor, while they would have several boyfriends and friends. In their free time outside of working hours, women often met with men fitting in all these categories for meals, trips to the beach, or shopping. They cautioned one another, though, that it was not worth "falling in love" with any of these men, who were unlikely to reciprocate and whose material support could be short-lived.

The categories of "sponsor" and "boyfriend" were somewhat fluid, but women especially sought to establish a sponsor. A sponsor might not see them every week but would provide them with substantial material support, such as return tickets home, regular monetary gifts, and occasional weekend vacations. Boyfriends could be upgraded to sponsors if their investment shifted from occasional 
meals and gifts to more substantial displays of material wealth, and for this reason women often fostered relationships with both a sponsor and at least one boyfriend simultaneously.

These relationships punctuated women's time, whenever they were not at the club dancing, and women assiduously kept track of their schedules so that they could be available when men sought to meet up. Frequently I would agree to go with a dancer to the steklari, as the dancers called the long stretch of Istaklal Caddesi with cafes, movie theaters, bookstores, and storefront after storefront featuring alluring clothing, shoes, or jewelry in their shop windows; and just as we began our window shopping, a cell phone would ring. "Oh, sorry, that was my boyfriend, and he wants to meet up," was something dancers often told me; spending time with an anthropologist posing constant questions rated well below the option of seeing a boyfriend. On other occasions when women had assessed that a boyfriend was not really providing material benefits and just taking up their emotional energy, they would use our outings as an excuse to give a boyfriend a cold shoulder.

All the entertainers also maintained ties with "friends." As Kara explained after one of her daily flirtations with a local fruit seller, and another time when she got a favorable price on a pair of shoes after flirting for several days with the shop assistant, "You just never know—it could be useful in the future-so why not flirt?" It was always possible that friends could be upgraded to become boyfriends, although less likely sponsors. Entertainers had a keen sense of the material circumstances of the men in whom they took an interest, and only those with considerable means would be seen as potential sponsors. ${ }^{22}$

\section{DARIA}

Women rarely claimed to be "in love" with the men they became involved with, and in cases where they did, it was considered unfortunate. This was the case with Kara's second roommate, Daria. She was on her third contract in Turkey and was thinking of how to negotiate her fourth. Daria often spoke of her eight-year-old daughter back home in southern Ukraine, who was being cared for by Daria's sister and was attending a private school funded by Daria's earnings. One afternoon Daria told me, "I'm just so tired, eight years without a break" (Ia tak ustala, 8 let rabotaiu bez pereryva). She flipped through some photographs she had just had developed and changed the subject, pointing to an image of a young Turkish man embracing her on a beach. She reflected that she felt lucky to have a boyfriend, someone who genuinely cared for her, but she worried about the relationship if she couldn't arrange work in Istanbul at the end of her club contract. Daria's roommates expressed concern, saying Daria was in trouble-she had fallen in love with this man, and it was not bound to work out. 
Instead of relationships premised on love, more often romance was mobilized in less permanent forms. Women were keenly aware that the relationships with men could be fleeting, and so they were careful to cultivate Turkish men they met who might potentially become sponsors, or at least boyfriends. One Sunday afternoon in 2002 when I accompanied nine of the dancers on an outing to the beach I observed how dancers went about this. At the beach I soon noticed that Kara and another entertainer were not swimming so much as flirting with several young Turkish men. They eventually exchanged phone numbers, and Kara later quipped that one could always use another boyfriend who could take you out or buy gifts, or even possibly become a sponsor who might lavish more significant resources on you. The man she often referred to as her sponsor had disappointed her recently; he had not called for two weeks, and Kara surmised he was trying to avoid feeling pressured to provide the money sponsors customarily gave to the entertainers for their return tickets home.

In other cases, like Daria's, Turkish men fell in love with entertainers, and this created its own problems in an intimate economy where love and money fit uneasily together. In an interview with Can, a Turkish club manager, he had been telling me about the workings of his club when he commented on how his former girlfriend performed there. Can said he missed his girlfriend terribly, but they could no longer be together. She insisted on continuing to work in the club even though he pleaded with her to just let him support her. As he said with exasperation, "I would have given her money! How can I be with her if she is dancing!" Can said he was simply perplexed as to why his ex-girlfriend would want to continue in such a profession, especially when he was sure she cared deeply for him. As the next portrait suggests, women's forthright accounts about their efforts to privilege economic stability over emotional concerns point to a disconnection between what men and women sought in intimate relationships.

\section{IRINA}

Irina, the woman who first introduced me to the figure of Hürrem/Roxelana, worked in a number of jobs back home in Ukraine-including as a baker, bookkeeper, and market vendor-before deciding to go to Turkey. As she explained, at home she had a great set of friends, her parents, her eight-year-old daughter, and some work. Things were more or less okay with her husband too; she noted: "Everyone said he was absolutely beautiful, and in bed he was fantastic! But he just did not want to work; there was no money in the household." Irina said she got tired of him and decided to move back in with her parents. Then in 2001 she left home for Turkey, leaving her daughter to be cared for by her parents.

One day after Irina and I visited the Kariye Museum, the Byzantine Chora church with its interior walls covered in stunning mosaics depicting biblical 
scenes, over tea Irina told me about the men who were her friends $\left(d r u z^{\prime} i a\right)$ in Istanbul. She said she was selective and had no need for men who did not have any money. "Why would I hang out with them? It is fine if they are nice guys, et cetera, but in Ukraine I had tons of such friends." As she explained, she left home "to find the guys with money ... why would I seek out the losers once again? ... All I want from life is a big kitchen and a chance to prepare food for a husband. I can't really afford to love anyone; no, I need to find a husband who can provide for me, but meanwhile I am here earning a living."

\section{Autonomy and the "Girlfriend Experience"}

While most of my interviewees were not as blunt as Irina about the need to find "the guys with money," a theme of avoiding the potential constraints of "love" in favor of economic stability and independence permeated their accounts. Some of them spoke of this in terms of autonomy they sought to establish—sometimes from former husbands, often from parents, and sometimes from boyfriends or sponsors. For the most part, women's concerns revolved around housing, wanting an apartment of their own, and the desire to live separately from their natal families on their return to former Soviet locations. In some ways this need for personal autonomy echoes the desires expressed by women migrants portrayed in other locations. In the case of Filipina domestic workers in Hong Kong, Constable (1999) writes about "ambivalent returns" to households in the Philippines, where women typically lacked the autonomy they had come to appreciate in Hong Kong. In Marie-Eve Carrier-Moisan's (2012) study of Brazilian women migrating to larger cities and engaging in intimate encounters with European men, she also found women frequently preferred the relative autonomy they could enjoy away from the demands of their natal families. Likewise, post-Soviet entertainers did not long for the demands of their households back in Ukraine, Moldova, Russia, and Belarus. Just like Filipina domestics in Hong Kong and women immersed in the sexscapes of eastern Brazil, many of the post-Soviet entertainers first left home for economic reasons but then found that they relished the individual freedoms they could enjoy as well. Working and living in Turkey provided women with a degree of control over their lives and a sense of independence, ideals they associated with being modern, fully realized adults, as reflected in the following two portraits.

\section{AKSANA}

As we sat in her room, Aksana arranged her clothing and cosmetics in a suitcase and spoke about her family. She recounted how her twenty-one-year-old sister lived with her infant son at her parent's home in Belarus; her older sister, in her 
thirties, lived with her son not far from their parents. Aksana said her parents knew she was in Turkey dancing, although they did not know that she danced topless. She did not seem too concerned about this and turned to laugh at her roommate's attempt to hide some condoms that had been left lying on the bed. At the time of our conversation Aksana was twenty-four and could not wait to get an apartment of her own; as she insisted, "I am not going to do this forever, [I will] just get established and get my apartment." Other entertainers had similar plans. For instance, Rita, an entertainer from a small town in Ukraine who dropped by during our conversation, chimed in: "I need a two-bedroom apartment in case I get married and things don't work out; I would rather be throwing out my husband than be on the street myself. If I need to, I would just get a roommate."

Prior to coming to Turkey, Aksana was employed as a seamstress for three years, but this paid poorly. She knew she would never be able to afford an apartment on that pay. Before that she worked abroad in Poland, where she picked fruit and tended gardens for three months. That was hard work, and she didn't want to work so hard for so little pay-just \$250/month. When we met in 2007, after just six weeks in Istanbul, she had been able to save $\$ 1,000$.

Although Aksana missed her family, she worried that if she went home she could fall into a standard life of marriage, kids, and low-paid job, a reality she found unappealing. Aksana was dismissive of marriage, saying perhaps in her thirties she would consider it. As she explained, "I don't want to be controlled by someone; I want to be independent" (Ne khochu byt' pod kontrolem; khochu byt' nezavisimoi). She saw her time in Turkey as a means to achieve her goal. She laughed, telling me she kept information from her boyfriend as a way of retaining control over her situation. For instance, she arrived to work in Turkey in 2006 and did not even tell him. He was in Ankara and thought she was in Belarus. She recalled the time before that, right when she was departing from Belarus, and he called on her cell. He pleaded with her to just come as a tourist to Turkey, just to visit him and not work. She brushed him off, pretending she needed to be home with her family, but in fact she was off for her next contract in Istanbul.

Despite the desire for personal autonomy that most of the entertainers expressed, like them Aksana also sought out the financial support of sponsors. As she explained, it was a delicate balance of maintaining control while still benefiting from the attention of a sponsor. Aksana's friend, a tall woman with big, dark eyes and long eyelashes, who was studying economics as a distance education student in Belarus, came by one afternoon as we were wrapping up our conversation. She and Aksana were planning their departure for Antalya, a trip that Aksana's Istanbul sponsor was paying for. The two women lamented that they would be missing the opportunity to earn at least another week's worth of 
pay at the club, but they were also glad to have a paid vacation in Antalya, and they were excited to see the beaches and to live in a nice hotel before returning to Belarus. Aksana reasoned that the trip also made sense because it might prevent one of her Istanbul boyfriends (not a sponsor) from getting the idea that she was too attached to him.

\section{IULIA}

Most women I met did not envision working as a dancer for more than a few years; however, dancing in Turkey was viewed by many as giving them more economic and sexual independence than other options they had. Women like Aksana spoke unflinchingly of Turkish men in terms of what could be gained from being in relationships with them—sometimes misleading them, always maintaining several boyfriends, and moving from one sponsor to the next. This was also the case with Iulia, a twenty-one-year-old woman from a small city south of Moscow who, over tea one summer afternoon in 2005 in Gezi Park, told me that she had dreamed of becoming a theater actress. Her parents had insisted she go into law, but six months short of completing her law degree in Moscow, Iulia decided she was tired of studying; she left university but was unable to find work. By chance she met a German tourist on the subway, and she ended up showing him around and then sleeping with him. At first she found the relationship exciting; they kept in touch over e-mail and she missed him when he was back in Germany. The German man visited her family several times, and Iulia described how, when he would call, her parents would begin using sugary language to greet him. Iulia mocked their tone, saying "my darling" ( golubchik moi). With a look of disgust and a flick of her cigarette Iulia recalled that when the German man invited her to be with him in Germany, her parents urged her to go. Ultimately, she did travel there but, as she explained: "It just did not work ... and I had to force myself. I just didn't feel for him in my soul." She returned home but again could not find work, so set out for Turkey.

At this point Iulia rearranged her long legs and the waiters at the Gezi Park tea garden quickly responded as she waved her arm for her cigarette to be lit. She ruminated, "The Turkish guys just get lonely since their religion does not allow them to really spend time with women." She added that it was much better to be in Turkey with these men than in Germany. In Germany she could not wait to leave. Her boyfriend wanted sex all the time, and there was no question of holding back. In contrast, Iulia viewed Turkish men as a sort of eager and polite audience for whom she could perform her sexuality but remain in control of it, without having to engage in sexual intercourse. As she explained: "Here I can go to restaurants, be gifted clothing and flowers, and be desired, but they will not do anything. ... I can easily play this out for another six months (Mozhno eto vse rastianut' na shest' mesiatsev)." 
Iulia's account underscores the instrumentality of many dancers but also the ways in which women see themselves as having a certain form of power unavailable to them in their daily lives back home or elsewhere. Like the women Elizabeth Bernstein (2007a) writes about working in northern California's intimate services economy, these post-Soviet women often emphasized how their work was about engaging in performances of intimacy. In Bernstein's analysis, she develops a useful concept of "bounded authenticity" to explore how escorts, and the men who sought their company, were involved in an intimate economy of the "sale and purchase of authentic emotional and physical connection" (2007b, 192). Bernstein describes how North American men seek out the "girlfriend experience" (GFE) because it is an efficient way to engage in intimacy, albeit in a commodified form; she argues that this makes sense in a neoliberal setting where men feel they cannot afford to take time away from work to nurture authentic relationships. In a sort of twist on Bernstein's formulation, the post-Soviet dancers in Istanbul were also concerned with time, money, and autonomy. Like the men seeking escorts in Bernstein's study, post-Soviet entertainers understood the GFE, or the BFE (boyfriend experience), as an efficient, relatively safe exchange, where women performed forms of intimacy that a girlfriend might provide, only without the burden and demands of a long-term relationship.

Iulia's account especially illustrates a situation I heard about frequently, where entertainers saw their work in contrast to the possibility of feeling powerless and trapped in a relationship. Iulia explicitly discussed capitalizing on sexualized intimacy that she could engage in on her own terms. She fled from a relationship where she did not "feel it in her soul," and where "true love" and her dependence on her boyfriend required her to be available for sex on demand, to a situation where she felt more in control of her body and her economic well-being. In Istanbul she was taking part in an economy of desire where being capable of performing intimacy was key. This was paired with a wide range of options for Iulia to deploy as she engaged men who were prepared to spend money on her. Iulia and other dancers I met were trying to capitalize on the perception of them as embodying sexuality "without hang-ups," even as they sought to maintain their own terms on how they would play out the girlfriend experience with men.

\section{Learning to Labor "without Hang-ups”}

Another significant aspect of dancers' narratives concerned the performance of sex work as a form of labor they had to learn. Some embraced the work, and others spoke of it like any other job, involving terms they agreed to in exchange for a paycheck. For most, learning to dance was an extension of other experiences away from home; for a few, the work was too alienating and they did not stay in the job. 
One afternoon in 2005 over tea and a few cigarettes in the hotel lobby, Anna and Sonia reflected on their first days in their jobs as entertainers. Anna, who was twenty-five at the time, recounted how she first began dancing a year earlier; her friend Sonia, who was twenty-one, started two years earlier. They spoke of the demands of the work as something they had adapted to, but recalled one dancer who had recently returned home to Ukraine. She was nineteen, "but acted like she was ten when she arrived," said Sonia, who described how the woman was disdainful of the work. During their shifts, when customers were seated at entertainers' tables, this woman refused to capitalize on the possibility of creating a girlfriend experience with clients. She also did not want to make small talk with men, and she could not bring herself to take part in coaxing clients to spend endlessly on overpriced drinks, one of the basic requirements of the job. Anna and Sonia concurred that the work was not for everyone.

In contrast, Sonia said she did not feel any anxiety about taking up this work, possibly because she learned to be on her own early on. As she explained, as a child in Ukraine every summer she went off to Pioneer camp, where she got used to living alone and fending for herself. ${ }^{23}$ She added that she knew what she was getting into and said, "It is not such a big deal, it's just dancing after all." Anna agreed that after their first week in the club in Ankara (where she and Sonia had their first contract), she also came to think of the dancing as no big deal. She added: "It is just a matter of perspective. If you relax and just see this as being at a disco, then it is fine. You can just go to work and enjoy dancing, and recall that this is just a job, at the end of which you get a paycheck; that's what made it okay for me, even though it was tough the first week." Anna described how in her first days in the job she called her mother in Ukraine for comfort. Her mother intoned, "It's not such a big deal. This is just a job and there is no need to be getting upset." Anna leaned close to me and added, "It is not as if we are having sex or anything; we just try to be bez kompleksov," once again invoking the expression often used by dancers to indicate a sense of unrepressed sexuality, or sexuality without "hang-ups." This ideal of sexuality without hang-ups could be seen as a global mantra for a generation of young people but especially young women seeking to capitalize on a demand for a particular type of authentic intimacy, possibly a key hallmark of global industrial capitalism, where service work, mobile populations, and postmodern family forms come together (Hochschild 1983; Bernstein 2007a; Cheng and Kim 2014).

\section{Performing Sexuality}

In addition to engaging in a global intimate services economy, however, these post-Soviet dancers shared some common history. They could be seen as taking 
part in a post-Soviet sexual revolution where, according to Igor Kon, "sexual freedom became one of the most important aspects and symbols of social liberation" $(1995,3)$. Although only a subsection of young people from former Soviet regions were labor migrants in Istanbul, these entertainers were very much part of a post-Soviet generational gestalt where there was a distinctive relationship to media and the benefits of money, as well as a positive association with the idea of sexuality "without hang-ups." ${ }^{24}$ In contrast to their parents' generation, sexuality was seen as fundamental to their subjectivity and something to be consciously performed and capitalized on.

Nearly all the women I interviewed reflected on the element of performance that came with their work. For instance, Aksana ruminated one afternoon, "All of life is one big game, a game about sex." She added, "All that matters in life is how good you are at this game." Other women spoke explicitly about enjoying the performance of sexuality and the relative respect they received from Turkish men. Irina, the woman from Ukraine who said she could not "afford" to love anyone, told me that she was not fazed by dancing in the club; in fact, unlike some dancers, she often enjoyed dancing topless. She described how in school she had been very shy, "like a mouse"; and she beamed as she recounted that on her first trip home from Turkey, she projected such a sense of confidence that one of her former teachers did not recognize her. One of Irina's favorite phrases, “These days you have to know how to work the situation" (Segodnia nado znat' kak podygryvat' situatsii), reflected her thinking about a sense of adaptable or even fluid identity. Irina also happened to identify as a devout Christian; the evening after we visited the Byzantine Chora church, she dropped by my hotel room with her Bible, thinking I might like to borrow it to peruse passages related to some of the iconography we had seen that day.

Other dancers never mentioned religious sentiments to me, but, like Irina, they were well aware of the way they consciously embodied a certain type of sexuality. This was a topic they especially linked to their choice of clothing. As Rita, the woman who planned to buy a two-bedroom apartment in case she had to throw out her husband, told me, she restricted her movements beyond the hotel and the club, and when she did go out in her free time, she avoided wearing provocative clothing in an effort to blend in. She explained that she avoided wearing even T-shirts that were too tight, since, "Why would I want extra attention anyway? I can meet men at the club." Other women reflected on how they changed their daily presentation of self when they arrived in Istanbul. Irina said that during the day she stopped wearing makeup, like the eye shadow and mascara that she had worn on a daily basis in Ukraine, because she got tired of the attention she attracted. Men were incessantly poking and pinching her, so when she had time off she decided to change her appearance, including wearing jeans 
instead of skin-tight stretch pants. These efforts to fit more seamlessly into Istanbul youth culture were echoed by women who were not working as entertainers; many domestic workers and shop assistants, like Raia, pointed to their efforts to downplay what they described as the "sexiness" (sexual'nost') of their outfits (e.g., short shorts, tight jeans, or low-cut blouses), at least during the day when they were traveling to work. Thus post-Soviet women migrants in Istanbul were constantly assessing how they were being received by Turkish society at large, and how signaling variable degrees of "sexiness" could work to their benefit.

In focusing here on post-Soviet entertainers and the intimate economies at work in their sojourns in Istanbul, I have sought to add a layer of nuance to how sex, mobility, and intimacy are frequently discussed. As I have argued, entertainers' lives were not simply about being underpaid, overworked, and victimized but were at least as much about women's aspirations and their efforts to realize their goals. The narratives of romance, love, and longing for independence invoked by women tell us about the emotional lives of migrants and, as with negotiations around intimacy, point to how private lives are being reshaped in a global economy.

Like women migrants in Hong Kong, Japan, and South Korea (Faier 2009; Cheng 2010; Constable 2014), post-Soviet entertainers forged distinctive intimate practices as mobile subjects. Often post-Soviet entertainers I met were like Aksana, excited to be relatively independent, earning their own disposable incomes; sometimes they were happily pursuing their own aspirations separate from families, boyfriends, and household responsibilities and commitments back in Ukraine, Belarus, Russia, Moldova, or even elsewhere in Turkey. Many young post-Soviet women I met discussed ways to make their sexuality "without hangups" work to their benefit. They spoke of their ability to navigate intimacy as a skill they had learned and as a currency they could deploy. Like Iulia, women were well-aware of how they provided a sort of girlfriend experience for their Turkish sponsors and boyfriends. The dancers I came to know were pursuing their own projects, often seeking by means of their mobility to take part in what they saw as a more modern, cosmopolitan way of being, albeit within the constraints of the service economy in which they found themselves.

Like Cheng, who found Filipina entertainers in South Korea to be employing "strategic intimacy" within unequal structures of power (2010), here I also see women's agency playing a key role in their encounters as entertainers whose options are, nevertheless, constrained by both post-Soviet and Turkish states. States make fundamental decisions about how to structure their economies, as well as how to regulate borders and bodies, and they also determine how difficult it will be to maintain documented and undocumented work. Women's work as 
entertainers depends on the mercurial Turkish state not policing entertainers' visa statuses too closely but also on their countries of departure not preventing them from traveling abroad. Moreover, states remain culpable for not providing the economic means for young women to work closer to home. Young women did not speak of youthful aspirations to work within the intimate services economy; instead many young women, like Kara, Iulia, and Daria, spoke of unrealized aspirations for careers in medicine, theater, or teaching, and they explicitly linked their migration to unsuccessful efforts to support themselves in their home countries' fledgling market economies. After finishing high school, they had sought work as secretaries, telephone operators, or vendors before turning to mobile strategies and strategic intimacy as a dependable source of income.

The history of Soviet sexual politics significantly informed how young women thought about their intimate practices, but they were also shaped by the flows of global capitalism. In a parallel way, Bernstein powerfully shows how, in the early 2000s, a quotidian erotic sphere more or less permeated public culture in the United States, albeit in tension with "traditional" ideas about sexuality and family (2007b). In setting the stage for her analysis of sexual economies in the United States, Bernstein writes that "the proliferation of forms of service work, the new global information economy, and 'post-modern' families peopled by insoluble individuals have produced another profound transformation in the erotic sphere" (2007a, 6). Like Bernstein, I link forces of global capitalism to shifts in intimate cultural practices; however, I do not see entertainers as "insoluble individuals." Entertainers I met were crafting selves that were deeply defined by prevailing global forces shaping intimate practices, but many entertainers' accounts reflect how performing the intimate "girlfriend" self in demand in Istanbul in the early 2000s also coexisted with other subjectivities. Although these women resourcefully sought out spaces for pursuing their projects of modernity, many were also deeply tied to their commitments in home communities. Like Daria and Irina, who were sending some of their earnings home to family members who were caring for their school-age daughters, or Kara and Nadia, who were supporting their mothers and brothers, many dancers I met were pursuing their own aspirations as well as providing for economic needs of family members. Dancers had realized a cherished dream of mobility, which they frequently saw as a first step to modern subjectivities, but nevertheless the women I met had traveled distinct routes deeply rooted in home communities. 


\section{“OTHER MOTHERS," GRANDMOTHERS, AND THE STATE}

As a passenger on a small minibus making its way north to the capital of Moldova in the summer of 2004, I was accompanied by my toddler daughter and stepmother, along with eight other passengers packed in elbow to elbow. One young woman sitting next to me was departing for a housekeeping job in Moscow. She was leaving her ten-month-old daughter in the care of her husband and mother for the second time since the child was born. After the three-hour bus journey Sveta would continue her trek from Chișinău via an overnight train to Moscow. She sighed with resignation that she didn't know exactly when she would be seeing her daughter again. Sveta's daughter, like nearly one-quarter of children in Moldova, was growing up with at least one parent away as a labor migrant (UNICEF 2009).

When our planeload of passengers bound for Chişinău was significantly delayed at Istanbul's Atatürk International Airport in 2011 I heard yet another account of how a family was raising a child through a transnational nurturing arrangement. Tania, a friendly woman with long blonde hair and bright blue eyes who was returning to her family in a small town in Gagauzia, told me that since 1997 she had traveled to Istanbul for regular stints working as a domestic for six months at a time. She and her husband rented an apartment and took turns traveling for short visits home to Moldova. Tania's sixteen-year-old son was barely two years old when she and her husband began leaving him with his grandparents; as she told me, "I thought a long time about leaving my son, but in the end it really helped when I told myself that lots of women have done this, and it is really necessary for me to raise him this way; he is a smart boy and wants to go on to study mathematics." 
I encountered many young women like Sveta and Tania reflecting on their negotiations around mothering from a distance, arrangements that often extended from their children's infancy well into early adulthood. In many instances, as children grew they were cared for by a close relative who oversaw daily needs, while mothers', and less often fathers', remittances financed basic necessities and educational opportunities, like private school or music lessons, as Daria and Niki had done for their daughters. In interacting even briefly with migrant women, I would hear about the decisions women were making regarding their children and implicitly about what I call a "transnational nurturing nexus," or the complex ways that families and households were providing for children by combining historical caregiving practices with investment in transnational circuits of mobility (Rouse 1992; Hewlett 2013) extending primarily between Istanbul and southern Moldova but also to Russia, Romania, and sometimes even farther from home. In this chapter I explore the idea of a transnational nurturing nexus involving "other mothers," as well as state-funded institutions such as day cares, in an effort to move beyond a focus on mother-centered care as a cultural universal (Glenn 1994) and, instead, to direct attention to the diverse, historically situated practices that shape nurturing. ${ }^{1}$

As women migrants like Sveta and Tania shared their reasoning with me about having others care for their children, I wondered about these decisions and the specific contours of this transnational nurturing nexus. I learned that children left for years in the care of their grandmothers or aunts sometimes referred to them as "mama," and when called to the phone or to a Skype conversation to speak with long absent biological mothers, children would be called to speak with their "other mother," in Russian drugaia mama. Children's separations from parents were not always easy, sometimes requiring reconfigurations of households or creating strains for parent-child relationships, but such caregiving practices were common, and nurturing by "other mothers" has a long history in the region, dating to well before Moldova's incorporation into the Soviet Union. Overall, I trace my argument about other mothers in Moldova in connection with a tradition of feminist scholarship on nurturing, mothering, and "othermothering." I argue for thinking about the transnational nurturing nexus many southern Moldovan women are part of as shaped by global economic restructuring and demands for gendered labor but also as rooted in local histories of nurturing practices. In the pages that follow I consider the local histories of "other mothering" in southern Moldova, but first I turn to some ways scholars have theorized about motherhood.

\section{Other Mothers and Shifting the Center}

Beginning in the 1970s feminist scholars looked to find universal frameworks for understanding gender inequality (Lewin and Silverstein 2016, 10-12). Around 
the same time influential theories examining mothering as a social practice emerged (Glenn 1994, 4-5), and these prompted an abundance of research and debate dedicated to the diverse forms nurturing can take and the relative weight of biological and cultural factors (Stack 1974; Collier et al. 1982; Moore 1988; Scheper-Hughes 1989; Collins 1990, 1994). Black feminist scholars posed one of the strongest critiques of universalizing theories, with Patricia Hill Collins (1994) arguing that feminist theorizing paid scant attention to particular ideas about motherhood and the contexts in which they were generated. Collins writes, "Black women's experiences as bloodmothers, othermothers, and community othermothers reveal that the mythical norm of heterosexual, married couple, nuclear family with a nonworking spouse and a husband earning a 'family wage' is far from being natural, universal and preferred, but instead is deeply embedded in specific race and class formations" (1990, 222-23). Collins urges us to be attentive to the diverse experiences of motherhood and, instead of pursuing generalizable theories, to "shift the center" of analysis to provide a more rich understanding of human experience (1994, 61-62).

Like Collins, a number of feminist anthropologists have critically assessed how motherhood, class, and assumptions about divisions between public and private spheres play out in different locations (Clark 1999; Berdahl 1999; Freeman 2007). In her study of market women in Ghana, Gracia Clark found that middle-class, Western ideals of "self-effacing, homebound wife and mother" that were on the rise from the 1980s into the 1990s $(1999,719)$ did not map easily across cultural contexts and time. Instead she documented the way women's paid work among market women in Ghana was seen as an integral part of motherhood. Likewise, Daphne Berdahl (1999) demonstrated how, following the fall of the Berlin Wall, socialist frameworks combining positive valuations of work and motherhood collided with discourses placing women firmly in the home; East German women were no longer meant to be "worker-mothers," with women's paid labor highly valued along with their reproductive roles, and instead they became simply "mother-consumers" (Berdahl 1999).

More than twenty years earlier, in what remains a touchstone for scholars interested in a critical analysis of mothering, Carol Stack (1974) authored an ethnography of a community of midwestern African Americans living in the "flats." Stack's work contested deeply held assumptions about the forms mothering and nurturing could take in North America and showed how kin and those providing nurturing are "those you can count on." Stack's important study was one of the first to powerfully point to the central role of kin and networks-what some scholars, like Collins (1990), would later call "othermothers," rather than biological mothers_-as a basis for nurturing and community, especially for people on the margins. 
In thinking about nurturing practices in southern Moldova I draw on the rich scholarship around mothering and motherhood as I reflect on "othermothers" the various people, not always biologically related to children, doing caregiving in southern Moldova — and "other mothers," the relationship that Nelli's granddaughter and others sometimes invoked in referring to their often physically absent biological mothers. While the former emphasizes the mothering practices of those other than a biological mother, the latter focuses on "other" or "different" ways of being a (biological) mother, including by providing material and emotional support from a distance. The phrase "other mothers" preserves how this idea was expressed in southern Moldova, emphasizing biological mothers as the "other mothers" - not the primary caregivers but still taking part in a transnational nurturing nexus in a different, or "other," way that involved channeling resources in the form of remittances without being physically present. Although my emphasis is on "other mothering," namely how biological mothers who are not physically present but nevertheless take part in mothering practices, both processes, "other mothering" by transnational migrant mothers and "othermothering" by a wide network of people, are at work in southern Moldova.

Scholars have shown how "othermothering," "child shifting," and child fosterage are critical for communities throughout the world, especially as heightened precarity brought about by an intensified global economy compels family members to be absent as transnational labor migrants from months to years on end (Ehrenreich and Hochschild 2002; Schmalzbauer 2004; Leinaweaver 2010; Bledsoe and Sow 2011; Chamberlain 2013). Based on her ethnographic research among British-Caribbean families, Mary Chamberlain argues that child fostering or "child shifting" — with grandmothers raising grandchildren in Jamaica, Barbados, and Trinidad while their parents migrate for work in Britain-is a practice that has emerged over hundreds of years $(2013,305)$. In dispelling dominant theories focused on an idea of adaptation to economic circumstance, Chamberlain instead shows how such a family formation preceded even migration movements in the late nineteenth and early twentieth centuries and can be seen as enabling migration, rather than being a consequence of it $(2013,305)$. Likewise, Jessaca Leinaweiver (2010) shows how historically grounded practices of child fosterage in Peru insure companionship for aging parents, even while children are provided for, thereby enabling parents to engage in transnational migration to Spain.

Southern Moldovan women's experience of other mothering has parallels with experiences portrayed both in the rich literature on African American mothering practices and in the emerging literature on transnational nurturing practices being forged by diverse migrants. While I did not encounter the phenomenon of "community othermothers" that Leah Schmalzbauer (2004), Chamberlain (2013), and Collins (1990) describe, where a nonbiological mother takes 
it on herself to serve as a community resource and support for a wide number of nonkin children, nurturing of children by "othermothers," and most often grandmothers or aunts, was common among the households I came to know. Most significantly, southern Moldovan women's experiences of arranging for othermothering for children, like that described by Chamberlain (2013) for the Caribbean and Leinaweaver (2010) for Peru, demonstrate that this type of family formation is not just a desperate attempt to provide care for children. Instead it is a dynamic, historically based practice that enables women to become longterm labor migrants and provide substantially for their households. Nevertheless, migrant mothers' transnational mobility has also brought about a specific form of "other mothering" that is defined by nurturing from a distance. Migrant mothers have widely become the primary providers for households and thereby brought about changes in the long-term nurturing nexus in the region.

\section{Nurturing from a Distance}

A growing scholarship on transnational parenting examines so-called nurturing from a distance, an experience increasingly common for migrant men and women who are forced to leave children in the care of others for long periods of time. In particular, recent work on transnational parenting has asked how children fare under such arrangements. Overall, the absence of parents who nevertheless send remittances means improved material circumstances for children left behind, and while generally children initially express some degree of emotional distress, many are genuinely loved and provided for by caregivers (Gamburd 2000, 199; Mazzucato and Schans 2011,705). A number of studies have argued that children left behind may benefit materially while suffering at an emotional level (Schmalzbauer 2004; Parreñas 2005; UNICEF 2009). However, other studies have found the situation to be more complicated (see Carling 2012; Vanore et al. 2015). One study of well-being among children of migrant men in Southeast Asia suggests that the experience of transnational caregiving may be significantly shaped by cultural and historical factors (Graham and Jordan 2011). The researchers found that in two countries, Thailand and Indonesia, children expressed a sense of poor psychological well-being when their fathers were migrants, compared to children whose fathers were not migrants. In two other countries, Vietnam and the Philippines, there was no difference noted for children of migrant and nonmigrant fathers. Likewise, in a survey focused on the psychosocial well-being of Moldovan children aged four to seventeen with and without migrant parents, contrary to widespread assumptions, Michaella Vanore et al. (2015) found that children's psychosocial health was not directly determined by whether they had migrant parents. However, they did find that the gender of a child—overall, boys tended 
to fare worse than girls, especially if the father was absent-the gender of the migrant parent, and the caregiving arrangement all affected if and to what extent parents' migration corresponded to a decrease in a child's psychosocial health $(2015,258)$. All these studies provide a valuable perspective on how children fare, but they do not substantially consider the cultural practices and larger "nurturing nexus" that also shapes the experience of transnational nurturing.

In a few contexts, especially in Southeast Asia (Parreñas 2005; Graham and Jordan 2011) and Latin America (Schmalzbauer 2004; Leinaweaver 2010), the challenges of transnational nurturing are increasingly the focus of scholarly attention. In other locations, like the former Soviet Union, despite the widespread practice of women's transnational labor migration, local nurturing practices have not been widely researched in light of this mobility (however, see Keough 2006; Leifsen and Tymczuk 2012). The few references to transnational parenting in this region tend to make generalizations about contemporary migration as causing a deterioration of the "traditional family" and about what form nurturing practices take (e.g., nuclear families raising children) (Elrick 2008, 1513). Instead, I turn attention to what one scholar (Carsten 1995) has called "indigenous ways of acting out and conceptualizing connections between people," or "relatedness," to emphasize how nurturing practices are understood locally. As transnational mobility has recently come to define a life stage of young people in a number of locations, these conditions may forge new ways of connecting between parents and children, but they also build on practices that were already in circulation prior to the escalation in mobility brought about by weakened states and an intensified global economy. In focusing on the transnational nurturing nexus, or various elements contributing locally and across borders to realize caregiving in southern Moldova, we can gain a sense of local forms of relatedness without resorting to models of cultural practices that would frame these as dysfunctional.

\section{Mother Love and "Not Enough" Care}

The stories I came to hear over and over in Moldova point to the personal costs of "mothering from a distance" but not necessarily to a sense of "abandonment" and "not enough" care that Rhacel Parreñas, for instance, traces for Filipino children left behind by migrating mothers (2005, 125-30). Parreñas details the ways in which the media and the Philippine government perpetuate a prevalent public sentiment that mothers "should" be providing intensive daily care for their children. This public sentiment, in turn, vilifies absent transnational mothers (but not fathers) for being insufficient nurturers, a refrain some of the youth in Parreñas's study also voiced. Parreñas's analysis revolves tightly around gender discourses that frame women as needing to be "martyr moms" $(2005,109)$, 
performing intensive nurturing practices even at a distance, in their efforts to avoid castigation. Parreñas emphasizes an untroubled link between dominant discourses and internalized gender ideals in the Philippines but leaves local histories, class inflections, and cultural practices around nurturing relatively unexplored.

Despite significant work on the implications of transnational parenting, within this literature there is little focus on variation across space and time in regard to nurturing practices. The important critique of "natural" bonds of "attachment" and "mother love" between children and parents, especially mothers (e.g., Scheper-Hughes 1989; Franzblau 2002), tends to get lost in writings on transnational mobility, as does the vibrant literature on "othermothers" and diverse forms of kinship (e.g., Stack 1974; Collins 1990). Instead, idealized middleclass forms of mother love and universal emotions are too easily reinscribed in portrayals of the pain of separation for women migrants and their children, leaving little room for thinking about diverse nurturing practices.

In taking a different approach, my portrayal of Moldovan migrants and their families parallels the work of scholars writing ethnography of the "particular" (Abu-Lughod 1991; Gamburd 2000; Constable 2003), which emphasizes stories, local practices, and history with the aim of avoiding the homogenization of difference. I show how the other mothering I encountered in Moldova and Istanbul does not simply reflect ruptures in care brought about by transnational mobility and pressures of global capitalism. Instead, it is part of a nurturing nexus of multiple layers of care. This nurturing nexus includes parents, grandparents, and extended kin but also state-sponsored spaces like day-care centers and residential schools. Intimate practices of child rearing were reconfigured with the end of the Soviet Union and the subsequent economic pressures placed on households. In addition, there are continuities in the logics of nurturing drawn from an earlier era of caregiving. I argue that the prevalent practice of children being raised by "othermothers" with "other mothers" (biological mothers who are physically absent) taking part to various degrees, is integrally tied to the "other" forms of nurturing that have defined this region over the past century, including as state structures sought to transform how women balanced their lives as workers and mothers.

\section{Mothercraft and Maternalist Policies from the Soviet to the Post-Soviet Eras}

From the beginning of the Soviet era, motherhood posed an ideological challenge for the state. The state sought to transform women into productive citizens who could be worker-mothers, contributing to building the new socialist society 
through their role in the workforce and through their education of new generations. Nevertheless, in the early 1920s to 1930s, as urban migration flourished and at least twenty-three million men and women moved from rural areas into urban centers to take up work, children were not welcome and were generally seen as a "burden" preventing women from being productive workers (Denisova 2010, 56). ${ }^{2}$ Motherhood and traditional child-rearing practices were frequently framed as standing in the way of forging a new, industrialized society; and new forms of "mothercraft," or means of caring for and educating young children, were introduced to address this problem (Waters 1992, 123; Ransel 2000; Kirschenbaum 2001).

Within months of the 1917 Revolution, village women especially, seen to be steeped in religious and "backward" ideas, became the primary subjects of efforts to transform childbearing and child-rearing practices. ${ }^{3}$ Without any tsarist network of public kindergartens or day-care centers in place, educators had a daunting task; even in Moscow in 1917 only 2 percent of the preschool-age children attended any form of kindergarten (Kirschenbaum 2001, 37). As part of their vision of "social upbringing" (vospitanie), the Bolsheviks planned to establish nearly five thousand preschools across the Soviet Union by the early 1920s. These goals were not easily met in the conditions of civil war that extended for more than three years after the Bolsheviks came to power, and by 1919 even in urban centers, only 5-12 percent of all preschool-age children were served by these newly imagined educational institutions (Kirschenbaum 2001, 38). ${ }^{4}$ More than a decade later, even though there was a significant increase in preschool institutions, the majority of children did not attend them and, in fact, fewer children attended them in 1931 than in $1921 .^{5}$

This gradual reduction in preschool programs between 1921 and 1931 was partly due to the economic constraints faced by the Soviet Union but more to a shift in political aims. The retrenchment in social policy embodied in the new family code of 1926 not only reinscribed conservative social mores around marriage and sexuality but also reinstituted the family as critical to forging new socialist citizens (Goldman 1993). The state's prior commitment to the "withering away" of the family and supplanting parents with preschool institutions gradually waned. Instead, "small comrades" were to be forged though the joint efforts of newly "socialist" families and preschools (Kirschenbaum 2001). ${ }^{6}$

Along with what Lisa Kirschenbaum calls the "unabashed sentimentalization of motherhood" that emerged by the mid-1930s $(2001,133)$, child-care programs were once again officially expanded, including with plans to extend into rural areas. New family code legislation in 1936 also introduced a range of maternity benefits, including monetary payments for low-income mothers and mothers with "many" children, repercussions for fathers shirking alimony payments, and more prenatal 
and postnatal medical care (Denisova 2010, 73-74). However, due to inadequate staffing, lack of political will at local levels, and unequal access to social benefits for urban and rural dwellers, many of the legislated changes remained only on paper, especially in rural areas, until after the Second World War.

The most significant components of the campaigns to transform mothercraft involved establishing rural health care centers and child-care facilities, both of which were ultimately important for women's participation in the newly collectivized agriculture (Kuroglo and Filimonova 1976; Ransel 2000, 44-79). The Soviet government was especially anxious to expand the availability of child care, both to induce women to have more children and to incorporate more women into the paid workforce; between 1928 and 1940 the number of day-care centers across the Soviet Union increased more than tenfold, with collective farms often providing child care in some form (Denisova 2010, 165). ${ }^{7}$ Still, these efforts remained particularly fraught with internal tensions around pronatalist policies, on the one hand, and prolabor policies with insubstantial social support for families, on the other (Kirschenbaum 2001).$^{8}$ As an illustration of this situation, Eva, the woman whose household hosted me during extended stays in southern Moldova, recounted how stressful it was for her to get to work on time when her son was in preschool in the mid-1980s. Having her son in preschool made it possible for her to take on a position of responsibility at the hospital, but because the preschool opened at the same time she had to be at work, and she absolutely could not be late for work, she had frequently had to leave off her five-year-old to wait ten minutes outside the gate while she rushed off.

As late as the 1970s, child care was still not plentiful, especially in rural areas. For children under two years old there were widespread shortages, but also for three- to five-year-olds day-care shortages were widely recognized (Madison 1972, 831-32). In urban areas fewer than 50 percent of all eligible children attended day care, and in rural areas only 30 percent. In the early 1970s in the Vulcănești region, there were reportedly twenty day-care centers, as well as some "seasonal" ones, established under the aegis of collective farms (Kuroglo and Filimonova 1976, 30), yet a shortage of adequate child care persisted. This meant that in most rural areas, like the majority of Moldova, through the 1970s young children were being cared for primarily by family members, often by grandmothers who were retired from wage work.

In rural areas the crisis around child care was exacerbated by the lack of provision for maternity leaves. Under Soviet law all able-bodied people of working age were required to work (outside their homes). However, until the late 1960s only urban women had access to maternity leave and child care (Denisova 2010, 78-80). (Two to four months' maternity leave was granted to urban women as early as the 1930s.) Only in 1965 were rural women who were employed in 
collective farms granted maternity leaves of two-and-a-half months, and only in 1968-1969 were rural dwellers granted the same pensions, sick leaves, and maternity leaves as urban dwellers (Ransel 2000, 131; Denisova 2010, 73-80). Furthermore, in many rural areas, like southern Moldova, women waited well into the late 1970s to gain access to post- and prenatal care (Ransel 2000, 239). The biggest changes to the provision of social support for women and children were felt in the 1980s, when financing for children's hospitals, maternity wards, and prenatal centers significantly increased (Denisova 2010, 172). ${ }^{9}$

Despite the long-term rural crisis around health care and child care, even as early as the 1920s the Soviet state established boarding schools or residential schools (shkoly internaty) to educate school-age children and support women balancing the demands of motherhood and work (Makarenko 1973; Waters 1992, 128; Bloch 2003a). ${ }^{10}$ Initially these schools were also envisioned as places for children to gain access to a specialized education, for young street children to learn technical skills, or for indigenous Siberians to be inculcated with Soviet state-defined values. After the Second World War, when mother-headed households were common and the Soviet Union was extremely short on people of working age to join the labor force, residential schools of various types expanded countrywide to train students in vocational skills and make it possible for parents to work long hours (Ambler 1961; Ipsa 1994). In Moscow shuttle traders (and other Muscovites) told me that in the 1940s and 1950s, when their parents had long factory shifts, it was not uncommon for children to be left during the week at a residential school and only go home to parents on their day off. This system functioned into the post-Soviet era as well. For instance, in central Siberia in the early 1990s a number of indigenous Siberian women educators told me they were able to complete their professional training by periodically leaving their children in the local residential school while they traveled, sometimes over two thousand miles, to attend professional meetings or meet the biannual inperson exam requirements of distance education programs based in Leningrad (St. Petersburg).

Likewise, in southern Moldova people recounted how in the difficult postSecond World War years, as well as more recently, residential schools played an important role in cases when parents had no relatives with whom to leave children or grandparents were not capable of taking on the responsibility of caring for children. As in the case of an elderly woman I met in Vulcănești in 2004, who was petitioning to care for her grandson over the summer when he was not in school and his parents were still away as labor migrants, sometimes the residential schools worked in conjunction with parents or other relatives to care for children. Today there is a move away from any form of institutional care as Moldova undergoes a reform of its educational and child welfare systems and 
seeks out ways, including new forms of social support and financial payments, to have children remain in households, if not with parents or close family members (Kaufman 2009; UNICEF 2009). As I explore below, not only the systems of child care, but also public culture around parenting, and especially mothercraft, is again shifting in southern Moldova, as it is across many parts of the former Soviet Union.

\section{Postsocialist Nurturing and "Maternalist” Ideals}

Over the 1990s and early 2000s in Russia and neighboring formerly socialist states, legislation emerged that reflects shifting ideals around motherhood and a turn toward increasingly "maternalist" or "familialist" policies. While recognizing the benefits of these policies, scholars have critiqued them for elevating motherhood to a sacred role to which women should aspire above all else and for contributing to growing gender inequality (Temkina and Rotkirch 1997; RivkinFish 2010; Fodor and Kispeter 2014). ${ }^{11}$ In the case of Russia, in the first decade of the 2000s new policy measures significantly expanded socialist-era concerns with the "protection" of motherhood and children and instituted substantial financial benefits. For instance, in the last years of the Soviet era legislation was put in place that increased maternity pay and leave until a child turned three and also created a one-time payment to mothers at the time of a child's birth. Subsequent revisions to legislation in a post-Soviet era further inscribed maternalist ideals in a number of ways, including by extending maternity leave benefits to those adopting children, by guaranteeing full wages paid to mothers for up to eighteen months' leave, and by creating a provision for single mothers to receive child benefits until their child turned sixteen (Rotkirch et al. 2007; Denisova 2010, 168). Further legislation supported by President Vladimir Putin promoted an explicit pronatalist policy, where a one-time "maternity capital" payment of $\$ 10,000$ would be paid to each family that had a second child. ${ }^{12}$

In Moldova, as of 2016 there was no substantial "maternity capital" payment, but the state has nevertheless invested in maternalist policies that are meant to maintain the well-being of women and children. In 2014 benefits related to children were composed of three parts: maternity benefits, a "child-raising" allowance paid for up to three years, and a one-time birth payment. For maternity benefits, in theory women could receive 100 percent of their average earnings from the thirtieth week of pregnancy, for a total of 126 days. The child-raising allowance could be paid for up to three years and was calculated as 30 percent of a mother's average income for the six months preceding the birth. The one-time birth payment was 2,600 lei (about \$177 in 2016) for a first child and 2,900 lei (about \$190) for each additional child (US Social Security Administration 2014, 208-12). 
I met several women who returned from their work in Turkey or Russia to give birth and take maternity leave, but this was not simple. Although they could receive the one-time birth payment, because they worked outside Moldova and they had not paid into the social security system, they were only eligible to receive the child-raising allowance for eighteen months, at a fixed amount of 300 lei per month (less than $\$ 15$ in 2016). Furthermore, if they returned to their work abroad, they became ineligible to receive the monthly maternity benefit. ${ }^{13}$ Given the relatively meager material benefit, many women, like Sveta, the woman I met on the bus who was leaving her ten-month-old for the second time to return to work in Moscow, curtailed their maternity leaves. Instead they sought alternative care for their children so they could return to work within months of the birth of a child.

In addition to the various ways that post-Soviet states have sought to define how children are cared for, households have developed their own ways of providing for children, often drawing on historical patterns of care. In the late Soviet period it was common for children in urban households to spend long summer vacations with grandparents, and even to be primarily cared for by a maternal grandmother until they went to school at age seven, thereby freeing mothers and fathers to fully devote themselves to full-time study or work. While scholars have documented the long history of "extended mothering" in Russia (Rotkirch 2004, 160 ), wherein mothers, and especially grandmothers and less often a network of family and friends, take on parts of caregiving for children, the practice seems to be transforming. In Tatiana Tianynen-Qadir's (2016) study among bordercrossing Russian-Finnish grandmothers she shows how parenting in western Russia was rarely concentrated just within a tight nuclear household of motherfather-children, and today grandmothers also incorporate border crossing as a key nurturing practice in households. In urban Russia Jennifer Utrata (2011) writes about a striking increase in recent years of mother-grandmother-children households, what she calls "co-mothering," with little or no involvement of fathers (Utrata 2011). The extent of grandparent involvement is reflected in survey research among young adults in Moscow who were born in Russia in the 1990s. Of those surveyed, one-third had a grandparent (usually a grandmother) as a member of their immediate household, and three-quarters said that they had at least weekly contact with a grandparent. Most said they had a more intimate relationship with their grandmother than with either of their parents (Semenova and Thompson 2004, 126-27). ${ }^{14}$ In southern Moldova households have also historically employed their own versions of "co-mothering" and "extended mothering" to raise children, a pattern of care that women migrants described as intensifying as they were drawn into transnational labor migration with the end of the Soviet Union. 


\section{Nurturing from a Distance: Five Women's Narratives}

The forms of intimacy maintained with children and the role of caregivers were woven into wider narratives of women's efforts to migrate to Istanbul. Women recounted extended family support for children and often took for granted the historical practices of parents being separated from children for long periods of time. Frequently narratives pointed to domestic abuse, alcoholism, or the death of a partner during his stint as a labor migrant in Moscow as triggering women's own journeys as labor migrants. Even when male relatives were alive and active members of a household, they frequently had secondary responsibility for children, with children living instead with a female relative or close friend of the family.

Caregivers were not left entirely on their own to care for children, and younger children up to the age of seven often attended one of the six town-administered day-care centers for part of the day, while children from the age of seven attended one of the town's several schools. ${ }^{15}$ I had an opportunity to meet some of the primary caregivers bringing children to day care in 2004 when my daughter attended day care in Vulcănești. I learned that of the twenty-two children in my daughter's group, nearly half of them were living with a grandmother. I also learned from grandmothers that they considered their daughters to be too tough on their kids. The grandmothers complained that children found it hard when their mothers occasionally visited, especially since mothers were inconsistent with disciplining children and rarely adhered to the schedule the grandmothers had established for their grandchildren. Much like the caregivers for children of transnational migrants in Honduras (Schmalzbauer 2004, 1325), grandmothers I spoke to confided that they were ultimately relieved each time the parents' visits were over and they traveled back to work, because the children could finally resume their familiar routines. The fact that grandmothers were caring for grandchildren while daughters were away working was not viewed as a tragedy, just the most recent wrinkle in a long history of caregiving practices in the region.

As the following portraits of Raia, Maria, Niki, Polina, and Bella show, women negotiate a wide range of nurturing arrangements and in this way are deeply enmeshed in a transnational nurturing nexus.

\section{Extended Nurturing: Raia}

Raia, the woman who took her mother's advice to become Ahmet's girlfriend, is in many ways typical of women from multigenerational, extended families in southern Moldova (Kuroglo and Filimonova 1976; Guboglo 2006). In 2005 of her four siblings only Raia was in Istanbul, while one of her three brothers was working 
in St. Petersburg and the other two remained at home in Gagauzia. The brother working in St. Petersburg was married to a seventeen-year-old girl who lived with Raia's parents, waiting for her young husband to return and meanwhile completing high school. The other two brothers at home were teenagers and still in school but in some ways considered to be adults. One of them had a girlfriend, a teenage girl who had also come to live with Raia's parents. Given their professions-Raia's father was a carpenter and her mother a former state farm laborer-they could barely support themselves and their five dependents (the two sons and daughtersin-law, plus Raia's young son). Raia's economic contributions to the household were critical and followed the pattern established by her mother who, prior to being diagnosed with cancer, also briefly sent remittances home from Istanbul when she worked as a live-in domestic looking after children and cleaning.

Raia first decided to depart for Turkey after she left her husband; he used to beat her and lock her in the cellar when he got drunk. She was relieved to escape that situation. In 2006 Raia showed me a picture of her then five-year-old son dressed in a cowboy outfit she had sent from Istanbul. Raia moved her finger over his image and gave him an air kiss. She explained that while leaving her son with her parents for several years in a row was not easy, it was preferable to being home with no money. In the summer of 2006 Raia was especially proud of being able to send a red bicycle home for her son.

In some ways Raia's transnational nurturing practices, like those of many migrant mothers I met, fit with Anna Rotkirch's (2004b) description of "extended mothering," as involving mothers, grandmothers, and a network of family and friends, and linking rural and urban spaces. In a similar way, the transnational circuits of post-Soviet women's migration into Turkey are partly defined by the nurturing of children. In sending regular remittances and material goods home, Raia was enmeshed in a nurturing nexus involving aunts, uncles, and grandparents who cared for her son at home; the extended family enabled her to pursue work in Turkey and to maintain the transnational flow of resources.

\section{Grandmothering from Afar: Maria}

Unlike Raia, Maria, the woman who married a retired shoemaker in Turkey, did not have the benefit of a large extended household. Maria was compelled to leave Moldova in part because, like so many middle-aged migrant men who worked in Russia in the early 1990s, Maria's husband died in a work-related accident in Moscow while employed at a poorly regulated construction brigade (Reeves 2013; Bloch 2014). Shortly after this tragedy, Maria left for Turkey, sending a teenage daughter to live with her aunt and study in Moscow and leaving two sons, aged ten and twelve at the time, with a close friend's family in Moldova. 
Maria recalled how the friend who first convinced her to travel to Istanbul had a husband who was willing to stay home with their children, his daughter and Maria's two sons. Only later did Maria convince her own sister to look after the sons, but that did not work out either since the remittances she sent home were, in Maria's words, "drunk and squandered." Maria described how in her absence her sons ran around town "hungry" (golodnye) and were always on the streets playing without supervision. With her husband's family estranged, and her natal family back in Latvia, it was a constant struggle for Maria to arrange adequate caregiving for the children. ${ }^{16}$

Maria's sons did not finish high school, and although this was a disappointment for Maria, she was initially happy when they came to live with her in Istanbul. Soon after, however, supporting them became difficult. The sons made more than $\$ 100 /$ week working in a wholesale garment storefront, but they spent all their income on drinking and socializing, leaving their mother to pay the rent and cover food expenses for the household. When, in 2004, Maria fell in love with her future husband and soon married him, Maria was faced with a difficult decision; her husband did not smoke or drink, and although he was generally calm, Maria feared that he would be unwilling to live long with her rather wild sons. Coming to Turkey had been about supporting her sons' future, but now they had chosen their own paths and Maria was hesitant to allow her sons to ruin her chance to be happy.

Despite resolving to pursue some of her own aspirations, however, Maria's case also reflects a situation faced by a number of middle-aged women migrants I met who arrived in Istanbul in the mid-1990s to support young children or to help their older children pay for the cost of higher education. Once these children had grown, they sometimes continued to rely on their parents. As Maria said, "I am so tired; when will it stop? Each month I send off money to my children but it is time for them to work!" In 2013 Maria continued to send money, especially to aid her sons but also for her grandchildren in Moscow and Moldova.

When Maria's sons were deported from Turkey in 2007 and returned to live again in Moldova, one of them fathered a child. Although Maria's son did not play a role in his daughter's life, Maria felt compelled to provide some support for the mother of her grandchild. In this way, too, Maria was not unlike many mothers I met who were sending money and clothing to their grown children and grandchildren located both in Moldova and Moscow. In some cases this was in the form of a gift, not critical to the monthly household operations. However, as Tianynen-Qadir (2016) shows for transnational grandmothers moving between Russia and Finland, migrant grandmothers in Turkey were often an important source of support for young families, especially when the men were unable to work, had abandoned their families, or had become casualties of industrial 
accidents. In some ways this was a permutation of widespread nurturing practices in southern Moldova, just on a transnational scale. While transnational grandmothers' support was not automatic, more often than not grandmothers remained central to household incomes or, as in the following case, to caregiving for grandchildren.

\section{Other Mothering and Cell Phones: Niki and Nelli}

As women work abroad to provide for children, often sending substantial remittances home to finance their care and education, they participate in caregiving to varying degrees that can shift over time. Numerous factors influence their caregiving, including the amount of remittances they send and the degree to which caregivers depend on these remittances, the levels of intimacy between women and other caregivers, and the access mothers, children, and caregivers have to communication technologies. In contrast to those like Maria, whose children came of age in the early 2000s, for migrants arriving in Istanbul even just a few years later, the possibilities for communication had radically changed how women maintained ties with children and caregivers. If in 2002 one domestic worker in Turkey told me she felt fortunate to have found a relatively well-paying job where her employers would pay for her to make two phone calls home each month, by 2004 cell phone access had made such a benefit all but obsolete. Cell phone calls from Turkey to Moldova had become relatively inexpensive, and text messaging had become part of daily interaction. This technology was also key to my introduction to Niki; I first spoke to Niki in 2003 during one of her phone calls to her mother, Nelli, in Vulcănești.

In 2007 in Istanbul my daughter and I frequently met Niki when she would invite us to the wholesale clothing store where she worked as a shop assistant. One afternoon over tea at the store and later at her apartment around the corner where we enjoyed nonalcoholic beer as we watched a Bollywood film dubbed in Turkish, Niki spoke about her attempts to provide for her teenage daughter back home in Moldova. Like many men in the years immediately following the end of the Soviet Union, Niki's husband went looking for work in Moscow in the early 1990s. The first few years he was away, he returned home every few months, but by the mid-1990s his visits were more sporadic. Niki lived with her mother and her infant daughter, and they struggled to get by, given the small maternity benefit Niki received and the long stretches when her mother's salary as a bus driver went unpaid. Ultimately, Niki and her husband were separated, and Niki decided to go to Turkey.

Niki's mother, Nelli, had just returned from a stint in Turkey, so she was able to advise Niki on the best way to find work and how to avoid trouble with the local 
police. Like the mothers of many of Niki's friends and classmates, Nelli agreed to become the primary caregiver for her five-year-old granddaughter. Niki's daughter eventually got to know her father, but for nearly seven years she did not see him, and she came to think of her mother, who visited for several weeks once or twice a year, as her "other mother," and her grandmother as "mama." Nelli was proud of this relationship, and in recounting her granddaughter's early years said: "I was the one who always bathed her, even when her mother was home.... I took care of her."

Niki tried hard to be in frequent communication with her mother and daughter. For the first several years it was expensive to call, but the advent of widely available and affordable cellular phone service by 2004 radically changed the intensity of contact migrants could maintain with home. Calling became affordable, and texting and Skype opened up a world of frequent instant contact. Both when I met Niki in 2005 and in subsequent years when I visited her in Istanbul, she maintained close ties with her mother and daughter by calling or texting with them several times a day. Niki worried about her daughter's exam results in math, Moldovan, and English, all of which would determine her further academic opportunities. She also firmly supported her daughter's desire to play the flute, and Niki made sure that her mother had the necessary money for tuition. Niki was not physically present on a daily basis. However, her daily conversations with her daughter insured that she weighed in on important decisions and was well informed about her daughter's general well-being. She also invested her energy in encouraging her daughter and reminding her regularly that she had ambitions for her.

In some ways Niki's nurturing from a distance reflects family forms and practices described for Russia (Rotkirch 2004; Utrata 2011), where daily care of a child is often shared by a mother and a grandmother. However, even though the close communication that Niki maintained with her mother and daughter mirrored such physical proximity, the nurturing practices Niki and Nelli engaged in were more akin to what Collins portrays for "othermothers" (1990, 119-22) among African Americans. In the case of othermothering, mothering is a matter of a relationship built around nurturing and not grounded in direct biology; in fact, when Niki's daughter referred to her grandmother as "mama" and her mother as "other mother" (drugaia mama), this reflected the degree of relatedness she had with each of them, not the degree of biological closeness. Furthermore, the transnational space through which Niki nurtured, and the importance of communication technologies, introduces another nuance, namely how "othermothering," where biological mothers take part in mothering but not as a primary, physically present figure, was facilitated. As part of a transnational nurturing nexus of the early twenty-first century, cell phones and Internet technology 
have facilitated family forms that enable migrant worker-mothers to maintain meaningful channels of intimacy with their children and other members of their households, while also pursuing their own aspirations for work and travel.

\section{Othermothering as Enabling Migration: Polina}

The distinction between "othermothering" and "other mothering" is especially vivid where, for various reasons, women removed themselves from an active role in raising their children. This was the case for Polina, a coworker of Niki's brother to whom he first introduced me in the summer of 2011 in Istanbul. When we met, Polina was dressed in a black T-shirt and black stretch pants shot through with sparkles and was carrying an array of parcels as gifts for her upcoming visit to her hometown, a Gagauz village in a region of Ukraine bordering Moldova. Later that week Polina invited me to her apartment and over tea told me about her life in Turkey. She explained that she had first come to Istanbul in 1997, when her pay of $\$ 60$ a week as a shop assistant was more than ten times what she could make at home. She came to Istanbul to escape her abusive husband, whom she had struggled to make peace with for more than ten years.

Polina's departure was not a sudden one. Each time she clashed with her husband, she took refuge with her sister who advised her to leave for Turkey and promised to help look after Polina's son. However, Polina was anxious about leaving her fourteen-year-old son of a previous marriage, so she persevered in the relationship. Polina finally decided to take action, applying for and receiving a passport. Her neighbor, who had worked in Turkey for years, offered to help her find work and a place to live, and most important, she promised not to tell her husband where to find her. Polina borrowed money from her sister and traveled by bus from Vulcănești, via Romania and Bulgaria, to Istanbul.

Polina was afraid to return to southern Moldova, but she missed her son, and after eight months she decided to try to work out the relationship with her husband. Although Polina found her son doing well living with her husbandapparently her husband had formed a strong bond with her son from a very young age-she was unable to smooth over her own relationship with her husband. In fact, they fought fiercely soon after her return, and her husband took the opportunity to condemn Polina, calling her a "Turkish whore" (Turetskaia shliukha). Polina said she did not hesitate to pack her bags and return to Turkey, and she did not make another trip home for several years. Her son finished high school but to her disappointment did not go on to higher education. He got married in his early twenties and had two children, but the marriage did not last. At the time of our conversation Polina sent monthly remittances to her exdaughter-in-law to help support her grandchildren. 
Polina's narrative highlights how othermothering and kinship networks are key to enabling women to become transnational migrants. Polina was able to draw solace from her sister's promise to look out for her son, and this helped her make a definitive decision to leave for Istanbul. In addition, the fact that her exhusband got along well with her son made it easier for her to make a new life in Istanbul; in effect, even though Polina could no longer live with her husband, as a dependable caregiver for her son Polina's ex-husband was also part of a nurturing nexus that made it easier for Polina to pursue migration and remake her life, a life that did not include an active part as an "other mother" raising her teenage son. After working as a shop assistant for a number of years, Polina ultimately fell in love with a Kurdish man with whom she had lived for ten years when I met her.

\section{Histories of Othermothering: Bella}

In 2003, shortly after my daughter, stepmother, and I stayed briefly with Bella in her apartment in Vulcănești, Bella departed for work in Russia. I did not see Bella again until 2007, when we sat over dinner in the apartment I was renting in Moscow, and Bella spoke of her life. She shared a vivid and historically grounded account of othermothering as a cultural practice that had long shaped southern Moldova, and she also traced her experience of being a transnational other mother. Bella anchored her account of her family in histories of mobility stretching back more than a century. She described how, in 1880, at the age of five, her Albanian grandmother arrived in the region of contemporary Gagauzia (then Bessarabia) as a refugee fleeing the latest series of wars between the Ottoman and the Russian Empires; since she was without parents, she was taken in by a wealthy merchant family. ${ }^{17}$ She was well cared for and ultimately, at the time of her marriage, given land and even a small house. After marrying a local sheepherder, she gave birth to seven children-including Bella's father, who was born in 1912. Bella's father remained in the region and after going to Albania to earn a degree in Tiraspol, he returned to Bessarabia to become a much-loved teacher of physics and mathematics in the local school. The respect local people had for Bella's father was significant enough, even as late as the early 1980s, that Bella was given priority over others in the town administration's allocation of governmentowned apartments in the city center of Vulcănești.

The lineage Bella recounted was recognized even though she was, in fact, raised in a different household from her father's. In a pattern of adoption common to the region but not for girls, at the age of five Bella was sent by her parents to live with one of her father's brothers. As Elizaveta Kvilinkova writes, historically when a family adopted a child from relatives, the child was most often male and usually ten to twelve years old; frequently children were legally adopted and 
would become an heir to the family property, as well as having the responsibility to look after adopted parents in their old age $(2007,221) .{ }^{18}$ Bella explained her relatively unusual situation, telling how in her family there were very few children in her generation; three of her father's sisters did not have any children, while another had a daughter, but she died when an unexploded bomb from the Second World War detonated in the field where she was playing. Her father's brother, who inherited the family house and the family-run mill from Bella's grandfather, did not have any children. Bella's parents tried to send one of their sons to live at the family house and ultimately become the heir to the property. However, the son shied away from the hard work demanded of him and would not stay with Bella's aunt and uncle. Ultimately, Bella was sent and she settled in, enjoying the love her aunt and uncle lavished upon her.

There were few relatives around the large stone house until the 1970s. Of her father's siblings, his older brother and sister left for Romania in the brief window of time between the Soviet Union taking over power in the region (1941) and closing the border (1944). Another brother was sent off to Siberia in the late 1930 s as the representative of what was viewed as this "kulak" family, considered relatively rich since it owned the single flour mill in the area. Bella's much older siblings, twins, were toddlers at the time, and they were being cared for by Bella's mother's aunt because Bella's parents were studying in Kishinev. When they heard of the efforts to collectivize property in the region, Bella's parents traveled home to their village and found their twins in the arms of the aunt, who was sitting at the train station. According to Bella's account, their house had been taken by the local authorities, and the aunt and children turned out into the street; ultimately, Bella's aunt and all of her mother's family were "sent off to Siberia" for being wealthy landowners. ${ }^{19}$ Bella's parents made arrangements for the twins to live with Bella's father's family, and then they returned to their studies in Kishinev.

As Bella recounted a life punctuated by the fall and rise of empires, she also portrayed a local pattern of othermothering, wherein it was commonplace for family members other than parents to care for children. Bella told how, after two years of studying engineering (1978-1980), she got pregnant and, after giving birth and taking maternity leave, left her son with her aunt. The same woman who had raised Bella looked after her son so Bella could complete her education. Bella's aunt was alive until 1991, when she lost her battle with kidney disease, or she might have also cared for Bella's second son when Bella became a labor migrant several years after his birth.

In 1996 Bella was taking maternity leave from her job to raise her second child. Once her son began day care at two years old, she fully expected to return to her job as an engineer. However, although in the early post-Soviet period some former Soviet maternity benefits continued, by the mid-1990s these benefits had 
eroded, and one of the provisions that changed was a guarantee that mothers could return to their jobs after maternity leave. Bella learned that, contrary to her expectations, her job had not been held for her. As she described it:

This was a time of extreme economic hardship, with all kinds of people getting laid off, and it was clear that my only option was to go to Turkey to look for work. I left my sons with my husband and headed for Istanbul. ... It was easy to find good work; before everyone was going there, you could even choose between jobs. I found work with a family looking after two children for $\$ 400 /$ month, and I kept that job, happily working for nine months. I wanted to stay in Istanbul and see the flowers in the spring. I told my husband over the phone and he said, "I'll give you flowers ... you better get home!” so I ended up going home. I didn't really want to leave; that woman was really nice to me, and I got along so well with the kids. The woman was sad to see me leave since she was only able to get out with her husband when I was there to stay with the kids.

In the end, Bella worked in Istanbul off and on for nearly seven years. In 2002 her older son departed from home on a scholarship to study computer programming in Romania, while her younger son went to live with Bella's brother's family on the other side of town in Vulcănești; they had two small children, and it was less lonely for Bella's son than staying alone with his father. As Bella described it, her husband, a local policeman who worked long hours, began drinking in her absence, which made it more difficult for him to provide adequate supervision for their son. Bella returned annually for brief visits to southern Moldova, and in 2003 she left for Moscow. There she worked long days on an apartment renovation crew, and she looked forward to summers when her younger son would travel to Moscow to spend his vacations with her; in this way Bella was also engaging in "other mothering," while her relatives back in Moldova continued to provide the primary care for her son during the year. After living in Moscow for more than twelve years, in 2016 Bella moved back to Moldova.

\section{Other Mothers and a Transnational Nurturing Nexus}

A number of themes weave through the attempts by Raia, Niki, Maria, Polina, and Bella to nurture across borders. The mid- to late 1990s emerge as a traumatic time for families in the region. As the foundations of social stability disappeared almost overnight with the collapse of Soviet state supports, households faced financial crisis. Men were often the first to migrate in search of work on construction brigades in Russia. As in the case of Maria's first husband, many of 
these men did not return, and only after months of receiving no remittances did women learn that their husbands had died in work-related accidents or possibly found lovers. When men were present, like Raia's and Bella's husbands, they often sank into heavy alcoholism, and households struggled to stay intact.

In addition to household earnings suffering in this period, the state role in a nurturing nexus also diminished. The maternity benefits that had been in place in most former Soviet and East European countries dwindled in Moldova to levels that were no longer significant to households. ${ }^{20}$ As well, the maternity leave benefit, which had ensured one's place of work would be retained for two to three years (in the 1980s and into the 1990s) was no longer guaranteed in southern Moldova by the late 1990s. Moreover, by the 2000s benefits were paid according to one's last place of work, with women receiving their full pay for up to four months. However, if there was no last place of work, or if one had been self-employed, women were often ineligible for maternity benefits (Stewart and Huerta 2009, 162). ${ }^{21}$

Othermothering as a local nurturing formation enabling mobility also emerges from these accounts. As Kvilinkova writes about the late nineteenth and early twentieth centuries, "If a child was adopted at an early age by her aunt, then both women (the [biological] mother and the aunt) were called mother" (2007, 221). ${ }^{22}$ Like the linguistic practices Collins (1990) alludes to (e.g., "bloodmother" and "othermother") for diverse African American approaches to nurturing, linguistic practices in Moldova also reflect the othermothering vividly portrayed in women's accounts. Versions of these practices continue today as transnational worker-mothers, who were often raised by extended families themselves, now arrange for their own children to be cared for by grandmothers, aunts, and close friends.

Particularly Bella's account-but also Polina's, Niki's, Maria's and Raia'sreflects how the historical practices of othermothering in southern Moldova made it possible for women to imagine becoming transnational labor migrants. Turning to kin or friends was not framed as a desperate measure but as one that fit within a familiar cultural repertoire. As in Maria's and Polina's accounts, when parents or siblings could not care for children, it was not uncommon for women to turn to friends as either primary or assistant caregivers, and grandmothers often readily embraced caregiving as a normal part of the nurturing nexus defining their households. As Eva, who raised her sister Zina's children in the 1990s, said about her own and Zina's grandchildren in 2010, "Of course the grandchildren should stay with me so their parents can work more." In a way, this mirrors a pattern of what Rotkirch has called an "urban-rural nexus" around child care (2004b) that has typified family structures in Russia over the past hundred years, where children are often cared for by grandparents and older relatives in a rural setting, 
especially over the summer months, while a younger generation works or studies in cities. Likewise, similar to what Leinaweaver (2010) describes for Peruvian migrants and Chamberlain (2013) for Caribbean-British families, othermothering acts as a distinct caregiving form that is crucial to enabling transnational circuits of mobility between Turkey and Moldova, and sometimes Russia.

The distinctive nurturing nexus of care in southern Moldova goes beyond just familial support and instead consists of historically grounded practices and knowledge (e.g., adoption and expectations of state social support), as well as rapidly changing practices of what some in southern Moldova called "other mothering." This form of mothering, or nurturing from a distance provided by biological mothers, requires some form of othermothering or daily care and nurturing provided by grandmothers, aunts, and close friends, as well as some government institutions such as day-care centers, but it also increasingly involves biological mothers maintaining close and frequent emotional connections home via phone and Internet technology.

As for African American communities engaged in othermothering, in an era of a devastated local economy and an ineffective state, marginalized southern Moldovan communities have increasingly had to turn to "those you can count on" and rely on networks of kin and friends (Stack 1974, 90-107). Nevertheless, as Nelli's granddaughter emphasized in calling her mother Niki her "other mother," in analyzing the shape othermothering takes in Moldova, it is important not to elide the ongoing, nurturing from a distance that "other mothers," or migrant mothers, also frequently provide.

\section{Local Patterns of Nurturing or Universal Motherhood?}

Forms of mothering in Moldova raise important theoretical questions about how families negotiate support for one another, how transnational mobility may shape the ways caregiving is practiced, and how children experience being raised as part of a transnational nurturing nexus. Assumptions around an inalienable mother-child bond and mothering as innate have received extensive critique in recent decades, especially in the wake of Nancy Scheper-Hughes's (1989) work in shantytowns in Brazil, which destabilized prevalent assumptions about universal forms of "mother love." However, the phenomenon of migrant mothers prompts a renewed discussion of these ideas. As scholarship critically examines the implications of a globally feminized migrant labor force (Ehrenreich and Hochschild 2002), a growing volume of research, as well as popular news coverage, has emerged around the way children "left behind" especially suffer (Parreñas 2005; Coomes 2011). Framing analyses in this way reanimates Euro-American popular discourses of the 1970s and 1980s (Glenn 1994) situating biological mothers, 
rather than anyone else, as inherently better suited to nurture. The case of southern Moldovan othermothering and transnational nurturing suggests otherwise.

As Henrietta Moore writes, "The concept of 'mother' is not merely given in natural processes (pregnancy, birth, lactation, nurturance), but is a cultural construction which different societies build up and elaborate in different ways" $(1988,25)$. Moore goes on to state that the idea of "mother" is not only established through "maternal love, daily childcare or physical proximity" $(1988,26)$ but also through long-term material support, frequent communication, and sometimes more infrequent physical proximity but no less significant ties. From the perspective of North America, where the "cult of motherhood" took on new forms in the 1980s (Sanger 1996; Clark 1999), southern Moldovan women's relative ease with leaving their children for extensive periods might be seen as a conundrum.

It is striking that unlike many of Parreñas's Filipina respondents, who "sobbed" $(2005,115)$ during interviews, post-Soviet women did not exhibit this type of affect. Over the many conversations we had about transnational nurturing, unless I specifically prompted Moldovan women migrants, they rarely mentioned that they "missed" (skuchat') their children or felt guilty about leaving them back home. In reflecting on their migration, older women did tend to emphasize the need to educate their children, and younger mothers would often recount their migration histories and hardships with reference to those who were othermothering children back home. There are several factors that would seem to contribute to the differences in affect that Parreñas and I observed among transnational migrant-mothers. First, young people I met rarely had independent households, and when young women like Niki or Raia gave birth, they most often lived with their mothers. Given that young women's material and emotional lives were usually closely intertwined with those of their extended family, it makes sense that care for their offspring was also incorporated into this web of relationships and that othermothering became part of the nurturing nexus defining transnational migration. Second, and particularly key to my argument, is the distinctive nurturing nexus in southern Moldova that is inflected by histories of state support, or at least expectations of it, for worker-mothers and historical knowledge of how mothers, grandmothers, and othermothers balanced work and household tasks. In this way, both public discourse and social practice shape how women experience having children raised with othermothers but also the affect women express about others caring for their children. These transnational migrant mothers are "other mothers" who do not necessarily see an inherent conflict between mothering and (transnational) work (see Glenn 1994, 14-16).

Although histories of state support and practices of othermothering mitigate the ways in which women experience these migrations, they do not negate the widespread human suffering brought about by men's and women's large-scale 
outmigration from home communities. The stories of women labor migrants remind us of the social costs to structural readjustment in marginalized regions like southern Moldova. Especially when households are engaged in a transnational nurturing nexus in raising children, the lack of government support for households places an incredible strain on those upholding the various parts of the caregiving-financial, real time, and virtual. Even in these conditions of material hardship, it is important to avoid assuming universal frameworks around the experience of motherhood and the practices of nurturing and instead to look to the particular contours of transnational nurturing practices. As Raia's, Maria's, Niki's, Polina's, and Bella's accounts show, an analysis privileging biological mothers as primary caregivers would misrepresent the diverse other mothering practices interwoven with their transnational mobility. In thinking about the experiences of transnational migrants and their households seeking to forge multilayered forms of care for their children, ideally we can "shift the center," as Collins writes (1994, 61-62), and be cognizant of the historical continuities and creative measures shaping mobile mothers' nurturing practices in a world of growing precarity, shrinking government assurances, and increase in women's transnational mobility. 